\title{
Notes on the genus Anomala SAMouelle, 1819 (Coleoptera, Scarabaeidae, Rutelinae) in Vietnam and neighboring regions: eight new species and faunistic records
}

\author{
With 17 figures \\ Carsten Zorn ${ }^{1}$, HirokazU Kobayashi ${ }^{2}$ and KaORU WadA ${ }^{3}$

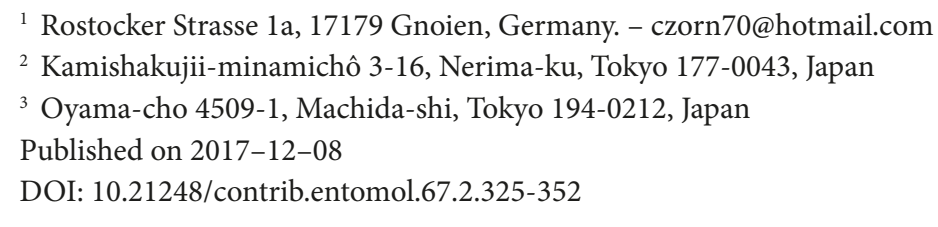

\section{Abstract}

Eight new species of the genus Anomala SAmouelle, 1819 are described from Vietnam: Anomala okushimai spec. nov., Anomala immeliorata spec. nov., Anomala confrater spec. nov., Anomala imperspicabilis spec. nov., Anomala ordinata spec. nov., Anomala recordata spec. nov., Anomala asaitoae spec. nov., and Anomala herbacea spec. nov. In addition, new and interesting records of Anomala species from Vietnam and neighboring regions are presented.

\section{Nomenclatural acts}

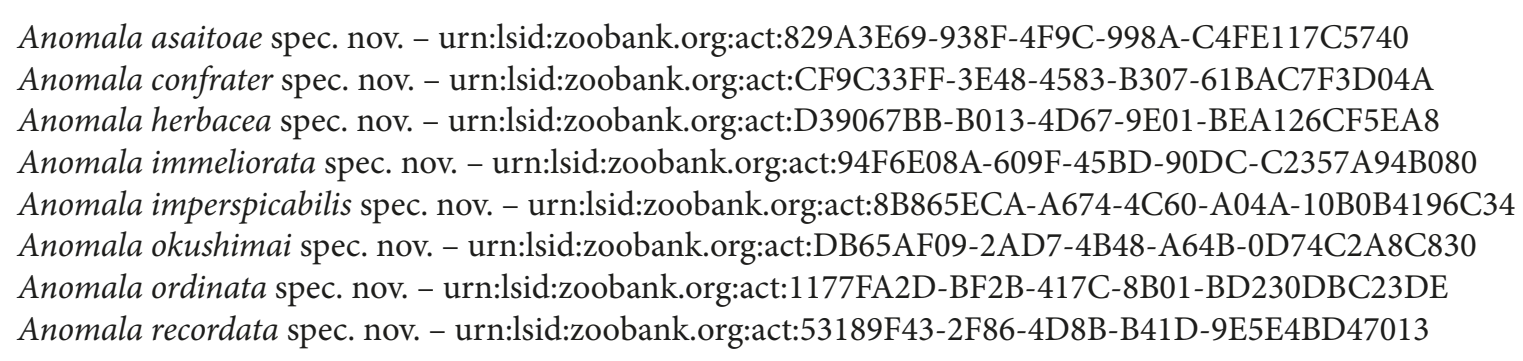

\section{Key words}

Scarabaeoidea, Southeast Asia, Laos, Thailand, Myanmar, Cambodia, China, taxonomy, faunistics

\section{Zusammenfassung}

Acht neue Arten der Gattung Anomala SAmouelle, 1819 aus Vietnam werden beschrieben: Anomala okushimai spec. nov., Anomala immeliorata spec. nov., Anomala confrater spec. nov., Anomala imperspicabilis spec. nov., Anomala ordinata spec. nov., Anomala recordata spec. nov., Anomala asaitoae spec. nov. und Anomala herbacea spec. nov. Ausserdem werden neue und interessante Funddaten von Anomala-Arten aus Vietnam und benachbarten Regionen präsentiert. 


\section{Introduction}

The focus of the present paper is the taxonomy and distribution of Vietnamese species of the genus Anomala SAmouelle. It also includes additional data of species from Laos, Thailand, Myanmar, Cambodia, and China. The knowledge on the taxonomy of Vietnamese Anomalini is currently growing rapidly. In the last 11 years alone nearly 40 new species of this tribe were described from Vietnam (Nguyen \& Wada 2006, Prokofiev 2012, 2013a, 2013b, 2013c, 2014, 2015a, 2015b, Prokofiev \& Zorn 2016, Zorn 2011). In this study, we describe another eight new species of the genus Anomala from northern and central Vietnam, as well as Laos, and provide faunistic records of species previously not known or rarely collected in Vietnam and neighboring regions.

\section{Material and methods}

Specimens were examined using a dissecting stereo microscope and fiber optic illumination. Habitus images were compiled using stacking and graphics software (CombineZP, Adobe Photoshop CS3).

The body length was measured from the apex of the clypeus to the apex of the pygidium. The length of pronotum was measured in the middle in dorsal view, its width at the place of greatest width. The ratio of interocular width to head width was measured in dorsal view at greatest width of head and nearest interocular distance. The terminology of elytral striation follows Zorn (2007). Type specimens of the species described in this paper bear the following labels: "HOLO-/PARATYPUS Anomala [species epithet] sp. nov. det. Zorn, Kobayashi \& Wada [year]". Different labels are separated by " | ". Labels are cited in their original spelling.

The holotypes designated in this study will be deposited in the collection of the Department of Zoology, National Museum of Nature and Science, Tsukuba (NSMT).

\section{Acronyms of depositories}

ANPC Collection Alexander Napolov, Riga, Latvia

ARPC Collection Andreas Reichenbach, Leipzig, Germany

ASPC Collection Andreas Skale, Hof/Saale, Germany

AWPC Collection Andreas Weigel, Wernburg, Germany

CZPC Collection Carsten Zorn, Gnoien, Germany

GEI Guangdong Entomological Institute, Guangzhou, China

HKPC Collection Hirokazu Kobayashi, Tokyo, Japan

HNHM Hungarian Natural History Museum, Budapest, Hungary

RBINS Institut royal des Sciences naturelles de Belgique, Bruxelles, Belgium

KWPC Collection Kaoru Wada, Tokyo, Japan

MFPC Collection Masayuki Fujioka, Tokyo, Japan
MNHN Museum National d'Histoire Naturelle Paris, France

MZUF Università di Firenze, Museo Zoologico "La Specola”, Italy

NHML Natural History Museum London, UK

NMBS Naturhistorisches Museum Basel, Switzerland

NME Naturkundemuseum Erfurt, Germany

NMPC Národní Muzeum, Prague, Czech Republic

NSMT National Museum of Nature and Science, Department of Zoology, Tsukuba, Japan

PLPC Collection Paul Lago, Oxford, Mississippi, USA

PPPC Collection Petr Pacholátko, Brno, Czech Republic

RIEB The Research Institute of Evolutionary Biology, Tokyo, Japan

SJPC Collection Stanislav Jákl, Prague, Czech Republik

SNSD Senckenberg Naturhistorische Sammlungen Dresden, Germany

UMO University of Missouri, Columbia, USA

VMPC Collection Vladislav Malý, Prague, Czech Republic

WFPC Collection Wang Falei, Chongqing, PRC

ZFMK Zoologisches Forschungsmuseum König, Bonn, Germany

ZMB Museum für Naturkunde, Berlin, Germany

ZMPC Collection Zhao Mingzhi, Guangzhou, PRC

\section{New species}

\section{Anomala okushimai spec. nov.

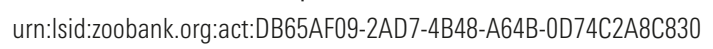 (Figs 1, 10)}

Type series: Holotype: $0^{\star}$, Tamdao VIETNAM 3rd vi. 1993 K. Matsumoto leg. (NSMT). Paratypes: $50^{\top} o^{\top}$, Tam Dao, N. Vietnam, 30-IV 6-V-1996, Y. Okushima leg. (MFPC); 1 o $^{\star}$, Tam Dao, Vinh Phu Prov., Vietnam, IV V1996 (MFPC); 1 o $^{\star}$, Mt. Tam Dao (alt. 900-950 m), Vinh Phu Prov., N. Vietnam, 14 18-V-1999, S. Nomura leg. (NSMT); $10^{\star}$, VIETNAM Tam Dao VII.97 BERNAUD leg. | Anomala gr. aulax (CZPC); 1 ․ N.-Vietnam Vinh Phu Prov., Tam Dao 01.-07.V.1998 Y. Arita leg. (CZPC); 1 o , 1 , N.VIETNAM (TONKIN) TAMDAO 12.-24.5.1989 PACHOLATKO Leg. (PPPC, CZPC); $1 \sigma^{*}$, Vietnam N, Vinh Phuc Pr. Tam Dao NP, 1000 m, N: 21²7,577'E: 105'38,489 V.2017, M. Pejcha lgt (CZPC).

Description: Body shape elongate ovoid, convex; body length: $16.7-18.0 \mathrm{~mm}$, width: $8.2-9.5 \mathrm{~mm}$.

Color. Dorsal surface except pygidium and propygidium deep metallic blue-green or green, sometimes with strong reddish reflections, antennae dark brown, basal two segment somewhat lighter; apical half of propygidium and pygidium orange-brown; pronotum with orange-brown lateral margins; ventral surface and legs predominantly dark metallic green; coxae, femora, lateral portions of thoracal segments as well as basal half of 
abdominal ventrites (sometimes obscured by greenish luster) and a spot at the sides of the abdominal ventrites 1-4 orange-brown.

Head with erect pale yellow setae $(0.07-0.13 \mathrm{~mm}$ in length) along eyes; interocular distance equals 0.73 times the maximum transverse head width. Antennal club 0.8 times as long as footstalk. Clypeus broadly trapezoidal to semicircular, densely punctate, the punctures partly coalescent and rugoso-punctate along marginal portion; anterior margin distinctly reflexed, with a shallow impression behind the margin at each side; fronto-clypeal suture almost straight. Frons densely punctate, punctures large (ca. 0.05-0.08 $\mathrm{mm}$ ), partly coalescent in the middle, becoming larger laterad, sparser and smaller posteriad. Vertex with rather sparse and fine punctures.

Pronotum 1.5 times as wide as long; sides convergent in anterior $2 / 5$, almost straight and subparallel in posterior 3/5; widest at base; anterior and lateral margin with weak marginal line; lateral marginal line extending to hind angles; front angles produced and acute, hind angles obtuse; disc with moderately fine, somewhat transverse punctures (ca. 0.05-0.07 $\mathrm{mm}$ ) which are intermixed with sparse microscopic punctures (visible under $40 \times$ ); with a vague longitudinal depression in the middle as well as a vague depression near the basal half of lateral margin and medially of the hind angles.

Scutellum 1.4 times as wide as long, apex angulate; with rather dense, somewhat transverse punctation.

Elytra regularly striate-sulcate; intervals moderately convex, primary costae slightly higher than interstices; sutural interval distinctly elevated in posterior $3 / 4$ of elytra; striae not marked by a regular row of punctures; entire surface covered with dense transverse, microscopic-seta-bearing punctures, leaving out only the ridges of primary costae and the humeral protuberance; punctures adjacent to each other, partly coalescing and forming small transverse striae; epipleura rather narrow, extending until apical curvature; marginal membrane starting approximately at level of anterior third of metacoxa.

Pygidium triangular, widely rounded at apex, somewhat tumid; with very transverse punctures which are adjacent to each other or confluate, forming a striolation which is arranged concentrically around the tumidity; each puncture bearing a microscopic seta (50x); longer pale yellow setae $(0.13-0.63 \mathrm{~mm}$ in length) along lateral and apical portion.

Mesoventrite very narrow and somewhat concave between the approximated mesocoxae.

Metaventrite reticulately rugulose, with long, decumbent yellow setae (0.13-0.38 mm in length).

Abdominal ventrites densely punctate, punctures strongly transverse, partly coalescent, bearing a short adpressed seta; additional transverse rows of semierect yellow setae (0.05-0.13 mm in length) in the apical half of the 2 nd to 4 th ventrite.

Legs slender and long; protibia bidentate; terminal tooth somewhat prolonged and obtuse at apex in male; protar- sal segment 5 with a stout, broad tooth at basal 1/4; inner protarsal claw and outer mesotarsal claw apically incised; the upper branch of the inner protarsal claw small and slender, the lower branch broad with a distinct tooth at its ventral margin; the upper branch of outer mesotarsal claw slightly more slender than the lower one.

Female: Body shape more stout; sides of pronotum slightly more rounded; terminal tooth of protibia spatulate; modified protarsal claw less enlarged, without ventral tooth.

Diagnosis: The similar shape of the aedeagus indicates a close relationship between this species, Anomala imperialis Arrow, 1899 and Anomala harpagophysa Prokofiev, 2014, but the parameres of the three are quite distinctive, and the latter two species lack adpressed setosity at the abdominal ventrites. Additionally, A. harpagophysa is distinctly larger and entirely metallic green with fiery red shine ventrally, while $A$. imperialis is smaller, and its elytral intervals have rather sparse and simple punctures (dense and transverse in A. okushimai). Moreover, A. okushimai is similar externally to Anomala aulax (WIEDEMANN, 1823) and its nearest relatives, but can be separated from those species by the following characters: pronotum narrower, with a transverse depression medially of the posterior angles; base of pronotum without marginal line; abdominal ventrites with distinct adpressed setosity.

Etymology: The new species is named after Dr. Yûichi Okushima, a Japanese entomologist and collector of several paratypes of this species.

\section{Anomala immeliorata spec. nov.

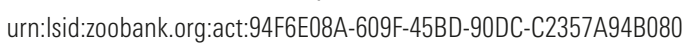 (Figs 2, 11)}

Type series: Holotype: ${ }^{*}$, C. VIETNAM: Quang Nam dist near Danang 16.IV.-15.V.2010. (NSMT). Paratypes: $1 \sigma^{\star}$, near Ngoe Thinh (alt. $2200 \mathrm{~m}$ ), Kon Tum Prov., C. Vietnam, 1-15-IV-2010, native collector leg. (MFPC); $3 \sigma^{\star} \sigma^{\star}$, C-VIETNAM Tua Thien Hue Prov. Bach Ma Natl.

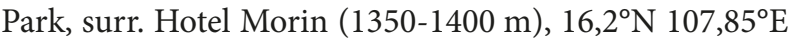
23-28.V.2014 (at light) / legit L. Bartolozzi, G. Chelazzi, A. Bandinelli, S. Bambi, F. Fabiano ( $n^{\circ}$ Magazz. 2978) (CZPC, MZUF).

Description: Body shape elongate ovoid, distinctly convex; body length: 18.0-19.5 mm, width: 9.0-9.5 mm.

Color. Entire body deep metallic green with reddish as well as faint iridescent reflections which are stronger on elytra, pygidium and abdomen; antennae greenish black, tarsi somewhat bluish.

Head with erect yellow setae (0.38-0.5 mm in length) along eyes; interocular distance equals 0.67 times the maximum transverse head width. Clypeus broadly trap- 
ezoidal, densely punctate; the punctures round and large (ca. $0.07 \mathrm{~mm}$ in diameter), partly coalescent along marginal portion; anterior margin distinctly reflexed; fronto-clypeal suture weakly sinuate. Frons densely punctate, somewhat larger anteriad, sparser and smaller posteriad. Vertex with sparse, small, somewhat transverse punctures.

Pronotum 1.7 times as wide as long; sides arcuate, convergent in apical $2 / 5$, almost straight in posterior $3 / 5$; widest at base; anterior and lateral margin with weak marginal line; lateral marginal line extending to hind angles; posterior margin with marginal line between hind angle and scutellum; front angles produced and acute, hind angles obtuse; disc with dense small transverse punctures (ca. $0.05 \mathrm{~mm}$ ) in the middle, punctures becoming larger laterad; with sparse erect yellow setae (ca. $0.6 \mathrm{~mm}$ in length) along lateral margin.

Scutellum 1.7 times as wide as long, apex broadly angulate; with sparse transverse punctures.

Elytra regularly striate-sulcate; intervals moderately convex; sutural interval elevated in the posterior $2 / 3$ of elytra; surface covered with irregular, transverse, microscopic-seta-bearing punctures; punctures adjacent to each other, confluent towards striae, much sparser and smaller at the ridges of the intervals and the humeral protuberance; epipleura disappearing behind middle of elytron; marginal membrane starting approximately at level of anterior third of metacoxa.

Pygidium triangular, widely rounded at apex; tumid; with reticulate striolation which is arranged concentrically around the tumidity; with reddish brown setae (0.63-0.75 $\mathrm{mm}$ in length) at lateral and apical portion.

Mesoventrite very narrow and somewhat concave between the approximated mesocoxae.

Metaventrite reticulately rugulose, with sparse yellow setae $(0.13-0.38 \mathrm{~mm}$ in length) in lateral portions, sparsely punctate and almost glabrous in the middle.

Abdominal ventrites transversely punctate in the middle, transversely striolate at the sides; 2 nd to 4 th ventrite with a transverse row of semierect brownish setae (0.08$0.38 \mathrm{~mm}$ in length) in the apical half.

Legs slender and long; protibia bidentate; terminal tooth prolonged and obtuse at apex in male; protarsal segment 5 with a sharp tooth in the middle; inner protarsal claw and outer mesotarsal claw apically incised, forming two branches; the upper branch of the inner protarsal claw small and slender, the lower branch broad with a distinct tooth at its ventral margin.

Diagnosis: Anomala immeliorata is a sister species of A. confrater and can be separated from it only by the shape of the aedeagus: the hook-shaped extension of the ventral plate is more strongly curved backwards, and the parameres are nearly symmetrical, not equipped with a lateral tooth (fig. 11). Both species are similar to A. aulax and A. imperspicabilis spec. nov. but can be separated from these by the following characters: pronotum without yellowish lateral margin and without median longitudinal depression; legs green; elytra evenly striate with very convex intervals; aedeagus distinctly asymmetrical in $A$. immeliorata and $A$. confrater.

Etymology: The specific epithet is formed by the Latin adjective "immelioratus, -a, -um" and translates as "not improved". It is an allusion to the unicolored and simple appearance of $A$.immeliorata compared to the similar A. aulax and A. imperspicabilis.

\section{Anomala confrater spec. nov.

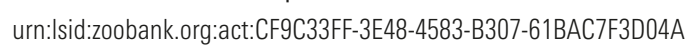 (Figs 3, 12)}

Type series: Holotype: $\sigma^{*}$, Tam Dao N. VIETNAM 28-30.IV.1991 M. Fujioka \& R. Muramoto -leg. (NSMT). Paratypes: $3 \sigma^{x} o^{x}, 5+9$, the same data as the holotype (MFPC); 1 ㅇ, Tam Dao, N. Vietnam, 7-V-1992, T. Miyata leg. (MFPC); $4 \sigma^{\star} o^{\star}$, Tam Dao, N. Vietnam, 4 6-V1996, Y. Okushima leg. (HKPC); $3 o^{\star} o^{\star}, 2$ 우 우, Tam Dao, N. Vietnam, V 1999 (KWPC); $10^{\star}$, Tam Dao, N. Vietnam, IV 2000 (KWPC); 2 우, Tam Dao, N. Vietnam, 16 VI 1997, S. Nomura leg. (KWPC, NSMT); $10^{\text {* }, ~} 1$, Mt. Tam Dao, Vinh Phuc Prov., N. Vietnam, 14 18-V1999, S. Nomura leg. (KWPC); 2 o $^{\star}, 2$ 우 + , Mt. Tam Dao, Vinh Phuc Prov., N. Vietnam, V-1999, native collector leg. (KWPC); $1 \sigma^{\star}$, Mt. Tam Dao, Vinh Phu N. VIETNAM 3-5 V 1994 Haruki Karube leg. | Kaoru WADA collection 2002 (KWPC); 1 o , Mt. Tam Dao, Vinh Phuc Prov., N. Vietnam, V-1999, native collector leg. (KWPC); $1 \sigma^{*}$, Mt. Tam Dao (alt. 900 m), Vinh Phuc Prov., N. Vietnam, 6-V-1999, S. Nomura leg. (KWPC); 1 o*, N.-Vietnam Vinh Phu Prov., Tam Dao 01.-07.V.1998 Y. Arita leg. (CZPC); 1 ㅇ , Tam Dao Vietnam 8.5.-22-5.1990 Dudvcha Miloč (CZPC); 1 o , 4 우 우, N.VIETNAM (TONKIN) TAMDAO 12.-24.5.1989 PACHOLATKO Leg. (PPPC, CZPC); 1 ㅇ, N-VIETNAM: Vinh Phuc Prov. Tam Dao National Park, $950 \mathrm{~m}$ 5.-12.VI.2010 L. Bartolozzi \& S. Bambi leg.; (nº Mag. 2894) (MZUF); 1 ơ, Vietnam bor. Pr. Vinh phu TAM DAO v. 1990 J. Picka lgt. | sp. 6 | coll. Vladislv Malý Česká Rep. Praha (VMPC); $30^{\star} 0^{*}, 3$ 우, Vietnam bor. Pr. Vinh phu TAM DAO v. 1990 J. Picka lgt. | sp. 6 | coll. Vladislv Malý Česká Rep. Praha (CZPC, VMPC).

Description: Body shape elongate ovoid, convex; body length: 18.0-19.5 mm, width: 9.0-10.3 mm.

Color. Entire body deep metallic green with reddish as well as faint iridescent reflections which are stronger on elytra, pygidium and abdomen; antennae greenish black, tarsi somewhat bluish.

Head with erect yellow setae (0.38-0.5 mm in length) along eyes; interocular distance equals 0.66 times the maximum transverse head width. Clypeus broadly trapezoidal, densely punctate; the punctures round and large (ca. $0.07 \mathrm{~mm}$ in diameter), partly coalescent along marginal portion; anterior margin distinctly reflexed; 
fronto-clypeal suture weakly sinuate. Frons densely punctate, somewhat larger anteriad, sparser and smaller posteriad. Vertex with sparse, small, somewhat transverse punctures.

Pronotum 1.7 times as wide as long; sides arcuate, convergent in apical 2/5, almost straight in posterior 3/5; widest at base; anterior and lateral margin with weak marginal line; lateral marginal line extending to hind angles; posterior margin with marginal line between hind angle and scutellum; front angles produced and acute, hind angles obtuse; disc with dense small transverse punctures in the middle, punctures becoming larger laterad; with sparse erect yellow setae (ca. $0.63 \mathrm{~mm}$ in length) along lateral margin.

Scutellum 1.3 times as wide as long, apex weakly rounded; with sparse transverse punctures.

Elytra. Regularly striate-sulcate; intervals moderately convex; sutural interval elevated in the posterior $2 / 3$ of elytra; surface covered with irregular, transverse, microscopic-seta-bearing punctures; punctures adjacent to each other, confluent towards striae, much sparser and smaller at the ridges of the intervals and the humeral protuberance; epipleura disappearing behind middle of elytron; marginal membrane starting approximately at level of anterior third of metacoxa.

Pygidium triangular, widely rounded at apex; tumid; with reticulate striolation which is arranged concentrically around the tumidity; with reddish brown setae (0.5-0.75 $\mathrm{mm}$ in length) at lateral and apical portion.

Mesoventrite very narrow and somewhat concave between the approximated mesocoxae.

Metaventrite reticulately rugulose, with sparse yellow setae $(0.25-0.38 \mathrm{~mm}$ in length) in lateral portions; sparsely punctate and almost glabrous in the middle.

Abdominal ventrites transversely punctate in the middle, transversely striolate at the sides; 2 nd to 4 th ventrite with a transverse row of semierect brownish setae $(0.13$ $0.25 \mathrm{~mm}$ in length) in the apical half.

Legs slender and long; protibia bidentate; terminal tooth prolonged and obtuse at apex in male; protarsal segment 5 with a sharp tooth in the middle; inner protarsal claw and outer mesotarsal claw apically incised, forming two branches; the upper branch of the inner protarsal claw small and slender, the lower branch broad with a distinct tooth at its ventral margin.

Female: Body shape more stout; sides of pronotum slightly more rounded; pygidium convex but not tumid; terminal tooth of protibia spatulate and rounded at apex; modified protarsal claw less enlarged, without ventral tooth.

Diagnosis: This species is closely allied to A. immeliorata and probably represents an allopatric sister species. Details of the shape of the aedeagus are diagnostic. The hook-shaped process of the ventral plate is less strongly curved and the right paramere is equipped with a distinct lateral tooth in A. confrater (fig. 12).
Etymology: The epithet "confrater" [Latin noun in apposition] is translated by "brother". It is alluding to the resemblance to A. immeliorata.

\section{Anomala imperspicabilis spec. nov.

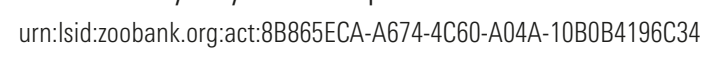 (Figs 4, 13)}

Type series: Holotype: $\sigma^{\star}$, VIETNAM Nghe An prov. Con Cuong JUN. 2008. (NSMT). Paratypes: 1 \% , the same data as for the holotype (MFPC); $10^{\star}, 1$ \% , LAOS-NE; HUA PHAN prov. BAN SALUEI; Phu Phan Mt.; $20^{\circ} 15^{\prime} \mathrm{N}$ 104어'ㄹ; 1500-2000 m; 26.iv.-11.v.2001 J. Bezděk \& D. Hauck leg. (CZPC); $9 \sigma^{\star} \sigma^{*}, 24$ ㅇ ㅇ, NE-LAOS: Hua Phan prov.; Ban Saleui, Phou Pan (Mt.) $\sim 20^{\circ} 12^{\prime} \mathrm{N}$, 10401'E; 1300-1500 m; 01.-31.V.2011; leg. C. Holzschuh Ankauf ZFMK Bonn 2011 (CZPC, PLPC, ZFMK); $280^{\star} o^{\star}, 25$ ㅇ ㅇ, NE-LAOS: Hua Phan prov.; Ban Saleui, Phou Pan (Mt.)- $20^{\circ} 12^{\prime} \mathrm{N}, 104^{\circ} 01^{\prime} \mathrm{E}$ 11.iv.-15.v.2012, 1300-1900 m leg. C. Holzschuh - ZFMK Ankauf 2012 (CZPC, ZFMK); 3 o $^{x}{o^{x}}^{-} 5$ 우 ㅇ․ NE-Laos: Hua Phan Prov., Ban Saleui, Phou Pan (Mt.) $-20^{\circ} 12^{\prime} \mathrm{N}, 104^{\circ} 01^{\prime} \mathrm{E}$, 11.iv.-15.v.2012, 1300-1900 m, leg. C. Holzschuh ZFMK Ankauf 2012/13 (CZPC, ZFMK); 5 o $^{\star}$, 1 우, NE-LAOS Hua Phan prov. Ban Saleui Phou Pan (Mt.) $20^{\circ} 12^{\prime} \mathrm{N}$, 104º1'E 11.iv.-15.v.2012, 1300-1900 m leg. C. Holzschuh ZFMK Ankauf 2012/13 (CZPC, ZFMK); 3 o $^{\star}$ ๙ $^{\star}, 3$ 우 우, NE-LAOS: Hua Phan prov.; Ban Saleui, Phou Pan (Mt.) $\sim 20^{\circ} 12^{\prime} \mathrm{N}, 104^{\circ} 01^{\prime} \mathrm{E} ; 1300-1900 \mathrm{~m}$ leg. C. Holzschuh 11.iv.-15.v.2012 - ZFMK Ankauf 2012/13 (CZPC, ZFMK); 7 ơ o o $^{\star} 5$ 우 ㅇ, LAO-NE Hua Phan Prov., $20^{\circ} 12^{\prime} \mathrm{N}$ $104^{\circ} 01^{\prime} \mathrm{E}$, PHU PHAN Mt., 1500-1900 m, 17.v.-3.vi.2007, Vit Kubáň leg. (NMPC); $280^{\top} 0^{\star}, 17$ , LAOS-NE, Houa Phan prov., 20¹3'09-19"N 10359'54"-10400'03"E, 14801510 m, PHOU PANE Mt., 22.iv.-14.v.2008 Vit Kubáň leg. (CZPC, NMPC); $10^{\star}, 1$ + , LAOS-NE, Houa Phan prov., $20^{\circ} 12-13.5^{\prime} \mathrm{N} 103^{\circ} 59.5-104^{\circ} 01^{\prime} \mathrm{E}$, Ban Saleui- $>$ Phou Pane Mt., 1340-1870 m, 15.IV.-15.V.2008, lao collectors leg. (NMPC).

Description: Body shape elongate ovoid, strongly convex; body length: 15.3-18.6 mm, width: 8.5-9.4 mm.

Color. Dorsal face metallic green, pronotum with vague narrow yellow border (lateral margin of pronotum and margins of elytra broadly suffused with yellow color in specimens from northern Laos); footstalk of antenna yellowish brown, club black; ventral face predominantly metallic green; mouthparts, sternal segments, femora and tibiae yellowish brown, meso- and metatibia with dark metallic green distal ends; tarsi dark metallic green.

Head with erect yellow setae (0.13-0.25 mm in length) along eyes; interocular distance equals 0.74 times the maximum transverse head width. Antennal club 0.8 times as long as footstalk. Clypeus broadly trapezoidal with broadly rounded front angles; densely punctate, the punctures round and partly coalescent; anterior margin distinctly reflexed; fronto-clypeal suture almost straight. 
Frons densely punctate, partly coalescent and rugulose in lateral portions, the punctures becoming larger and sparser postero-laterad; vertex irregularly scattered with smaller round punctures.

Pronotum 1.9 times as wide as long; sides broadly rounded, widest shortly before the base; basal marginal line almost complete, interrupted before the scutellum; front angles produced and acute, hind angles obtuse; disc with dense transverse punctures (ca. 0.05-0.1 mm); punctures partly transversely confluent towards front- and hind angles; with a distinct longitudinal medial furrow and vague depression in the middle of the lateral area; with erect yellow setae $(0.25-0.38 \mathrm{~mm}$ in length) along lateral margins.

Scutellum 1.3 times as wide as long, apex acute; irregularly scattered with somewhat transverse punctures.

Elytra. Regularly striate-sulcate; intervals moderately convex; striae not marked by regular rows of punctures; entire surface covered with very dense, transversely confluent punctures, forming small transverse striae; punctation sparser, separate and less transverse only towards the ridges of primary costae, at the humeral protuberance and behind the scutellum; epipleura rather narrow, disappearing shortly before apical curvature; marginal membrane starting near middle of metacoxa.

Pygidium triangular, widely rounded at apex; somewhat tumid; with very transverse punctures which are adjacent to each other or confluate, forming a striolation which is arranged concentrically around the tumidity; each puncture bearing a microscopic seta (50x); with sparse long yellow setae (0.13-0.45 $\mathrm{mm}$ in length) in apical portion.

Mesoventrite very narrow and somewhat concave between the approximated mesocoxae.

Metaventrite with very dense, transversely confluent punctation; with sparse, rather short, yellowish brown setae $(0.05-0.125 \mathrm{~mm}$ in length) in lateral portions; sparsely punctate and almost glabrous in the middle.

Abdominal ventrites transversely punctate in the middle, densely transversely striolate at the sides; 2 nd to 4 th ventrite with a transverse row of semierect brownish setae $(0.05-0.13 \mathrm{~mm}$ in length) in the apical half.

Legs slender and long; protibia bidentate; terminal tooth somewhat prolonged and weakly obtuse at apex; protarsal segment 5 with a sharp tooth at basal 3/5; inner protarsal claw and outer mesotarsal claw apically incised; the upper branch of the inner protarsal claw small and slender, the lower branch broad with an obtuse angle at its ventral margin; the upper branch of outer mesotarsal claw slightly more slender than the lower one.

Female: Sides of pronotum distinctly more rounded; pygidium not tumid; terminal tooth of protibia spatulate and rounded at apex; modified protarsal claw less enlarged, without ventral angle.

Diagnosis: Anomala imperspicabilis spec. nov. is very similar to Anomala aulax (Wiedemann, 1823). There appear to be no external characters that permit the separation of these two species. Details of the aedeagus, however, is distinctly different (fig. 13): the upper apex of each of the parameres ends in a branched, thorny structure, whereas it has a laterally curved, spine-like structure in $A$. aulax. The lower apex of each paramere is spatulate in A. imperspicabilis but hook-shaped in A. aulax. Anomala imperspicabilis is also similar to Anomala delavayi FAIRMAire, 1886, Anomala profundisulca Lin, 2002, and Anomala aulacoides OHAUs, 1915, but differs from these species significantly in the shape of the aedeagus. Anomala profundisulca and A. aulacoides have distinctly more convex elytral intervals than A. imperspicabilis, and $A$. delavayi generally has orange-brown femora and tibiae, strongly contrasting with the metallic green venter.

Remarks: All specimens of A. imperspicabilis found in northern Laos have a broad yellow margin on the pronotum and elytra; however, there appear to be no differences in the aedeagus. The taxonomic value of this color difference is yet unclear. More material from other localities is required to resolve this issue.

Etymology: The Latin specific epithet translates as "inscrutable" or "inapprehensible". It is an allusion to the unclear relation between the two known populations of the new species.

\section{Anomala ordinata spec. nov.

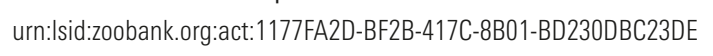 (Figs 5, 14)}

Type series: Holotype: $\sigma^{\star}, \mathrm{C}$. VIETNAM: Quang Nam dist near Danang 16.IV.-15.V.2010. (NSMT). Paratypes: $2 \sigma^{\star} \sigma^{\star}$, 2 우 우, C-VIETNAM Tua Thien Hue Prov. Bach Ma Natl.

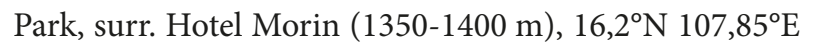
23.-28.V.2014 (at light) / legit L. Bartolozzi, G. Chelazzi, A. Bandinelli, S. Bambi， F. Fabiano ( ${ }^{\circ}$ Magazz. 2978) (CZPC, MZUF).

Description: Body shape broadly ovoid, rather weakly convex; body length: 21.1-24.1 mm, width: 11.8-12.7 mm.

Color. Entire body dark brown to reddish brown with strong iridescent shine.

Head with erect yellow setae (0.5-0.75 $\mathrm{mm}$ in length) along eyes; interocular distance equals 0.65 times the maximum transverse head width. Clypeus trapezoidal with broadly rounded front angles, strongly reticulately punctate; anterior margin enlarged and distinctly reflexed; fronto-clypeal suture weakly sinuate. Frons very densely punctate, punctures sparser and smaller medially and posteriad. Vertex with dense punctation.

Pronotum 1.8 times as wide as long; sides convergent in anterior $2 / 5$, almost straight and subparallel in posterior $3 / 5$; widest at base; lateral marginal line disappearing before reaching the hind angles; base without trace of marginal line; front angles produced and acute, hind 
angles completely rounded off; disc with dense, transverse punctures, each puncture bearing a distinct short seta which is approximately as long as the puncture; with erect brownish setae $(0.75-0.88 \mathrm{~mm}$ in length) along lateral margins.

Scutellum 1.5 times as wide as long, apex rather rounded; irregularly scattered with transverse punctures, bearing a short seta.

Elytra. Regularly striate-sulcate; intervals moderately convex; each stria marked by a regular line of round, well separated, hairless punctures; entire surface covered with strongly transverse, short-seta-bearing punctures which are partly adjacent to each other in proximity of the striae; irregular punctation denser near shoulder and apex; punctures becoming sparser and small towards suture; subsutural interstice covered with a mixture of both types of punctures in the central part, somewhat sulcate in the posterior half; elytra laterally somewhat flanged; epipleura strong, disappearing rather abruptly shortly before apical curvature; marginal membrane starting near middle of metacoxa.

Pygidium triangular, somewhat tumid and pointed at apex; with dense transverse striolation which is arranged concentrically around the tumidity; with scarce reddish brown setae (0.13-0.88 $\mathrm{mm}$ in length) in basal and apical portions.

Mesoventrite very narrow and somewhat concave between the approximated mesocoxae.

Metaventrite densely covered with partly confluent transverse punctures, with yellowish brown setae (0.25$0.5 \mathrm{~mm}$ in length) in lateral portions; sparsely punctate and almost glabrous in the middle.

Abdominal ventrites densely covered with very transverse punctures which confluate laterally, each puncture bearing a short seta; 2 nd to 4 th abdominal ventrite with a transverse row of semierect yellow setae $(0.3-0.38 \mathrm{~mm}$ in length); 1 st to 3 rd abdominal ventrite strongly carinate laterally.

Legs rather slender, moderately long; protibia bidentate; terminal tooth rather short, somewhat pointed at apex; protarsal segment 5 ventrally with a sharp tooth approximately in the middle; inner protarsal claw and outer mesotarsal claw apically incised; the upper branch of the inner protarsal claw small and slender, the lower branch broad, somewhat enlarged ventrally but without tooth; the upper branch of outer mesotarsal claw slightly more slender than the lower one.

Females: Body shape somewhat stouter, pronotum more convex and the sides more rounded; pygidium convex but not tumid, with impressions near each latero-basal angle; terminal tooth of protibia spatulate; modified protarsal claw less enlarged.

Diagnosis: Anomala ordinata is very distinctive in bearing very short but distinct setae on pronotum and elytra. The length of these setae approximately equals the length of the associated puncture. All other Asian species with distinct dorsal setosity, including those subsumed in the hirsutula-group (Lin 1996), have longer setae. Apart from the setosity, A. ordinata cannot be confused with similar species with sulcate elytra because of the combination of a large body size, a rather broad body shape and dark brown coloration. The structure of the boot-shaped aedeagus is unique within Anomala (fig. 14). There appears to be no closely related species.

Etymology: The specific epithet is formed by the Latin adjective "ordinatus, -a, -um" and translates as "put in order". It is an allusion to the evenly striate elytra in the new species.

\section{Anomala recordata spec. nov.

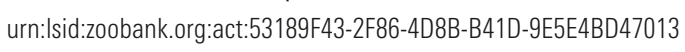 (Figs 6, 15)}

Type series: Holotype: $\sigma^{\star}$, C. VIETNAM: Quang Nam Da Nang 15-30. APR. 2009. (NSMT). Paratype: $10^{\text {* }}$, near Ngoe Thinh, alt. 2200 m, Kon Tum Prov., 1 15-IV-2010, native collector leg. (MFPC).

Description: Body shape elongate ovoid, strongly convex; body length: 18.0-19.0 mm, width: 9.0-9.5 mm.

Color. Dorsal surface entirely vivid metallic green with weak iridescent shine except as follows: footstalk of antenna reddish brown, pronotum with orange band along lateral margin, pygidium with orange spot at apex, elytra with a transverse zig-zag band before the middle, consisting of three pairs of orange patches appearing on primary costae 2, 3 and 4, the latter encompassing parts of the neighboring interstices; ventral surface metallic green except as follows: sides of sternal segments orange, femora orange, abdominal ventrites reddish copper with orange lateral spots.

Head with sparse erect pale yellow setae $(0.25-0.5 \mathrm{~mm}$ in length) along eyes; interocular distance equals 0.84 times the maximum transverse head width. Clypeus trapezoidal with rounded front angles and anterior margin; densely, somewhat rugosely punctate, punctures round (ca. $0.05 \mathrm{~mm}$ in diameter); anterior margin distinctly reflexed; fronto-clypeal suture weakly sinuate. Frons densely punctate, the punctures round in the middle, becoming larger anteriad, sparser posteriad. Vertex irregularly scattered with small, somewhat transverse punctures.

Pronotum 1.8 times as wide as long; sides arcuate in the middle; convergent and straight in apical 2/5, subparallel basad, widest at base; lateral marginal line almost reaching the hind angles; basal marginal line weakly indicated medially of humerus; front angles produced and acute, hind angles obtuse, rounded off; disc densely covered with transverse moderately small punctures (ca. $0.05 \mathrm{~mm}$ ), each puncture bearing a microscopic seta; with sparse erect yellow setae $(0.37-0.5 \mathrm{~mm}$ in length) along lateral margin. 

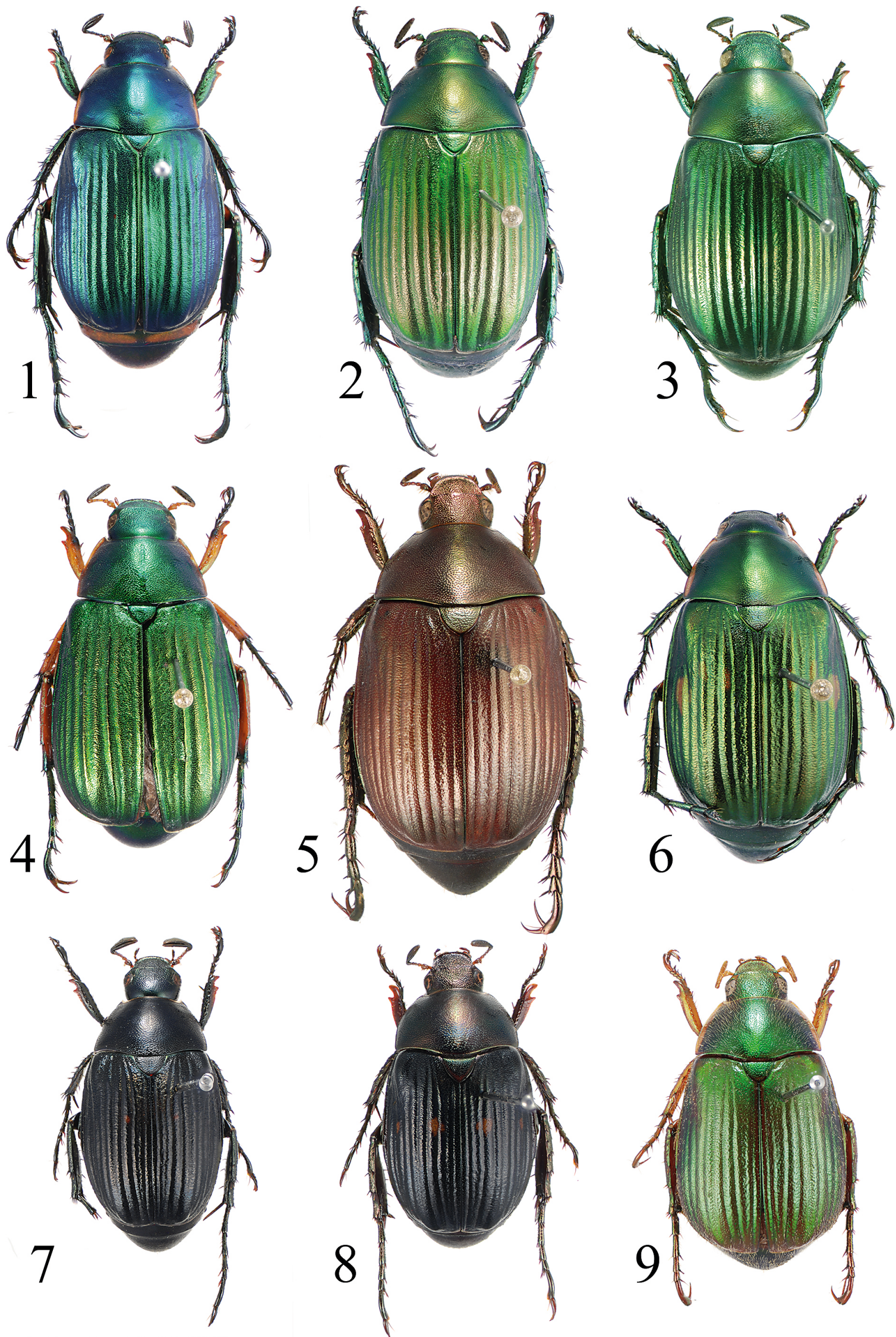

Figs 1-9: Anomala spp., habitus - 1. A. okushimai spec. nov., holotype. 2. A. immeliorata spec. nov., holotype. 3. A. confrater spec. nov., holotype. 4. A. imperspicabilis spec. nov., holotype. 5. A. ordinata spec. nov., holotype. 6. A. recordata spec. nov., holotype. 7. A. asaitoae spec. nov., holotype. 8. A. asaitoae spec. nov., paratype (female). 9. A. herbacea spec. nov., holotype. Scale $=10 \mathrm{~mm}$. 


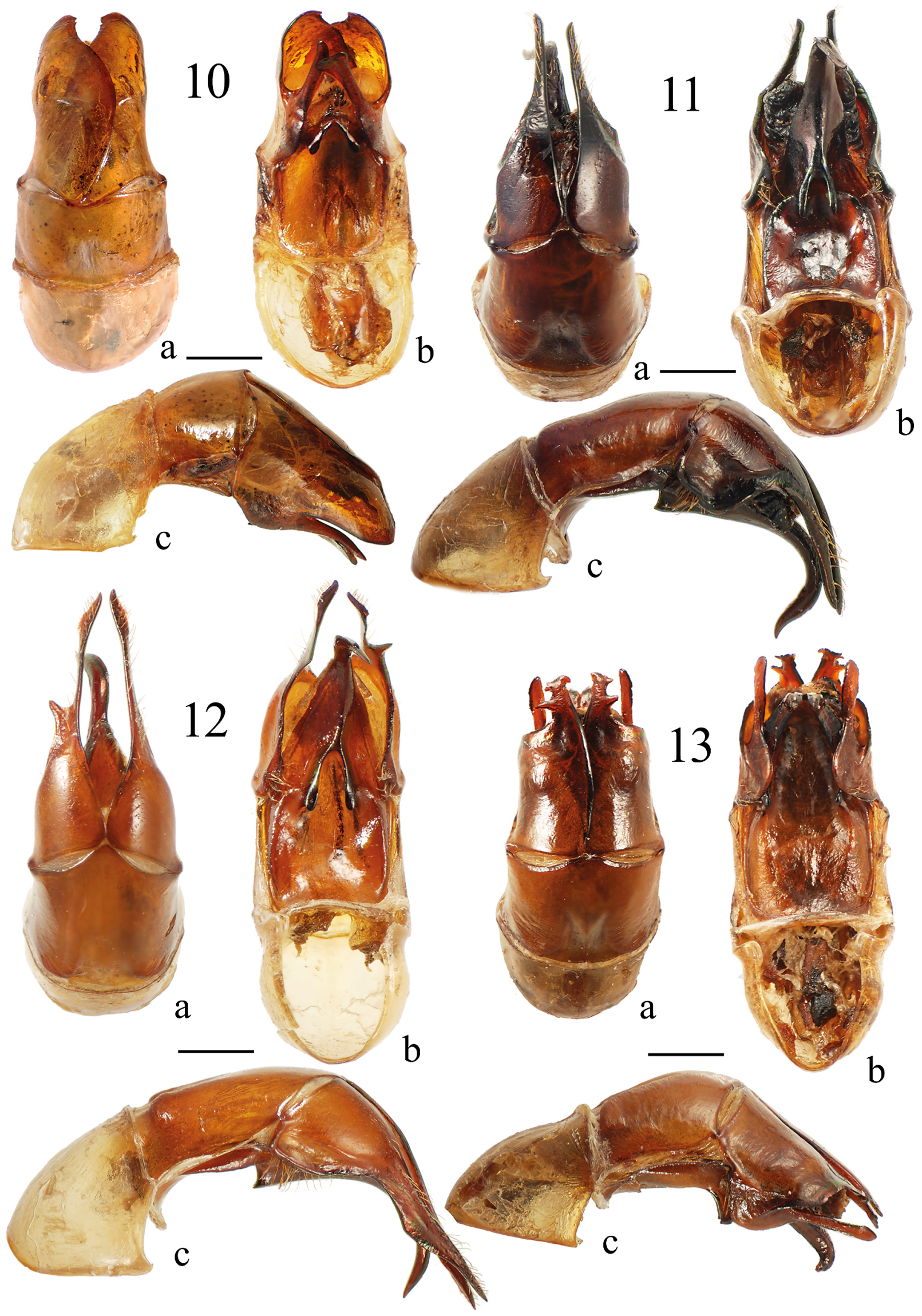

Figs 10-13: Anomala spp., aedeagus dorsal (a), ventral (b) and lateral (c). - 10. A. okushimai spec. nov., holotype. 11. A. immeliorata spec. nov., holotype. 12. A. confrater spec. nov., holotype. 13. A. imperspicabilis spec. nov., holotype. Scale $=1 \mathrm{~mm}$. 
Scutellum 1.4 times as wide as long, apex acute; punctures equal those of pronotum.

Elytra regularly striate-sulcate; primary costae distinctly convex, interstices weakly convex; with two vague secondary costae in the subsutural interstice; striae not marked by a regular row of punctures; entire surface covered with large, very transverse, microscopic-setabearing punctures, leaving out only the ridges of primary costae and the humeral protuberance; punctures adjacent to each other, partly coalescing and forming small transverse striae; epipleura ending before the apical curvature; marginal membrane starting approximately at level of anterior third of metacoxa.

Pygidium triangular and convex, somewhat tumid; disc with reticulate striolation which is arranged concentrically around the tumidity; with sparse yellow setae (0.1-0.75 $\mathrm{mm}$ in length) in apical and baso-lateral portions.

Mesoventrite very narrow and somewhat concave between the approximated mesocoxae.

Metaventrite with very dense, transversely confluent punctures at the sides, sparsely punctate in the middle; with pale yellow setae $(0.12-0.75 \mathrm{~mm}$ in length) at the sides which become sparser and shorter in the middle.

Abdominal ventrites with very transverse punctures which are separated in the middle and confluate laterally; 2nd to 4 th ventrite with a transverse row of semierect brownish setae $(0.2-0.63 \mathrm{~mm}$ in length, indistinct in the middle) and irregular short setae at the sides; sides not carinate.

Legs slender and long; protibia bidentate; terminal tooth prolonged and acute at apex in male; protarsal segment 5 thickened, ventrally with a deep concavity in the apical half; inner protarsal claw and outer mesotarsal claw apically incised; the upper branch of the inner protarsal claw small and slender, the lower branch broad, somewhat enlarged ventrally but without tooth; the upper branch of outer mesotarsal claw slightly more slender than the lower one.

Diagnosis: This species is a member of the group related to Anomala spiloptera BURMEISTER, 1855, all of which share a distinctive structure of the aedeagus: the parameres are usually very elongate and are connected by a wide wrinkled membrane dorso-basally. The ventral plate is usually equipped with a long process resembling a narrow blade. Many species related to A. spiloptera have different color variants. Within this group, A. recordata most closely resembles Anomala iridicollis OHAus, 1914 as well as the dark greenish forms of $A$. viridicostata Nonfried, 1892 and A. spiloptera Burmeister, 1855. It is, however, clearly separated from those species by the unique shape of the aedeagus (fig. 15) which is nearly symmetrical (strongly asymmetrical in A. spiloptera), and the ventral plate has a long, strongly downwards curved process (short in A. iridicollis, nearly straight in A. viridicostata). Moreover, males of $A$. viridicostata have protarsomere 5 distinctly more thickened, and in all specimens of $A$. iridicollis examined, the elytra were deep bluish black with orange spots, with rather weak metallic shine. Anomala recordata also has a rather broad subsutural interstice with two vague secondary costae. The subsutural interstice is distinctly narrower in A. spiloptera, while it is broad but rather flat in $A$. iridicollis.

Etymology: The specific epithet is formed by the Latin adjective "recordatus, -a, -um" and translates as "remembered" or "recollected". This alludes to the number of similar species with which it might be confused.

\section{Anomala asaitoae spec. nov.

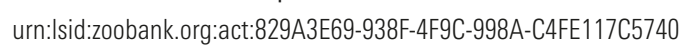 (Figs 7, 8, 16)}

Type series: Holotype: $\sigma^{\star}$, Truong Yen, Son La, VIETNAM, 1 v, 1995 A. Saito leg. (NSMT). Paratypes: $10^{*}$, 2 우, the same data as for the holotype (HKPC).

Description: Body shape elongate ovoid, convex; body length: $14.0-16.0 \mathrm{~mm}$, width: $7.0-8.3 \mathrm{~mm}$.

Color. Dorsal surface except antennae black; head and legs with faint bluish-green metallic luster; pronotum, elytra and pygidium with iridescent shine, antennal club dark brown, footstalk reddish brown; elytra with a small orange spot before the middle on each second primary costa ; ventral face black with greenish shine and iridescent reflections.

Head with sparse erect pale yellow setae (ca. $0.4 \mathrm{~mm}$ in length) along eyes; interocular distance equals 0.69 times the maximum transverse head width. Antennal club 0.8 times as long as footstalk; antennomeres 8 and 9 somewhat thickened. Clypeus subtrapezoidal with broadly rounded corners and curved anterior margin; surface rugoso-punctate; anterior margin distinctly reflexed; fronto-clypeal suture weakly sinuate. Frons confluently rugoso-punctate in the middle; the punctures becoming sparser and separate laterad and posteriad. Vertex with sparse, small, somewhat transverse punctures.

Pronotum 1.6 times as wide as long; sides evenly arcuate, subparallel basad, convergent anteriorly; widest at base; lateral margin hidden in dorsal view before the middle by a small protuberance; lateral marginal line almost reaching the hind angles; basal marginal line very weakly indicated medially of humerus; front angles produced and acute, hind angles obtuse, rounded off; surface evenly covered with transverse moderately large punctures; punctures larger and partly confluent towards the front angles, somewhat smaller on disc; each puncture bearing a microscopic seta; with erect yellow setae $(0.35-0.4 \mathrm{~mm}$ in length) along lateral margin.

Scutellum 1.6 times as wide as long, apex rather acute; with irregular, transverse punctures.

Elytra regularly striate-sulcate; primary costae slightly more convex than interstices; 5 th primary costa narrow and slightly more elevated than the others; striae not marked 
by a regular row of punctures; entire surface covered with large, transverse, microscopic-seta-bearing punctures, concentrating in the sulci, leaving out the ridges of primary costae and being sparser in the interstices; punctures adjacent to each other, partly coalescing and forming small transverse striae; humerus with rather simple punctation; epipleura strongly developed, abruptly ending at the level of second abdominal ventrite; marginal membrane starting approximately at level of middle of metacoxa.

Pygidium triangular, rounded at apex, somewhat tumid; disc with reticulate striolation which is arranged concentrically around the tumidity; with evenly distributed microscopic setae; longer sparse yellow setae (0.25$0.75 \mathrm{~mm}$ in length) in apical and baso-lateral portions.

Mesoventrite very narrow and somewhat concave between the approximated mesocoxae.

Metaventrite with dense, transversely confluent punctures at the sides, sparsely punctate in the middle; with pale yellow setae $(0.13-0.5 \mathrm{~mm}$ in length) at the sides which become sparser and shorter in the middle.

Abdominal ventrites with very transverse punctures which are partly confluent at the sides and sparser in the middle; each puncture with microscopic seta; each ventrite with a transverse row of semierect yellow setae (0.13-0.63 mm in length); sides of first abdominal ventrite slightly carinate.

Legs slender and long; protibia bidentate; terminal tooth prolonged and acute at apex in male; protarsal segment 5 thickened, ventrally with a little tooth approximately in the middle and a deep concavity in the apical half; inner protarsal claw and outer mesotarsal claw apically incised; the upper branch of the inner protarsal claw small and slender, the lower branch broad, somewhat enlarged ventrally with little tooth; the upper branch of outer mesotarsal claw slightly more slender than the lower one.

Females: Body shape stouter; antennal club not thickened; pronotum broader, more convex; lateral carina of elytra broadened behind middle; pygidium less tumid; terminal tooth of protibia spatulate; inner protarsal claw slender.

Diagnosis: Like the previous species, $A$. asaitoae belongs to the group containing $A$. spiloptera, recognizable by the peculiar dorsal connective membrane between the parameres (for details see "Diagnosis" of $A$. recordata). Within this group, A. asaitoae is differentiated by the enlarged two last antennal segments in males, the carinate sides of the first abdominal ventrite, the enlarged lateral margin of the elytra, the small body size and the unique, asymmetric shape of the aedeagus with spine-like apices of the parameres. The ventral plate has no apical process (fig. 16). None of the other species related to A. spiloptera has a similar combination of characters.

Etymology: The new species is named after Dr. Akiko Saito, entomologist at the Natural History Museum and Institute, Chiba, who collected the holotype of the new species.

\section{Anomala herbacea spec. nov.

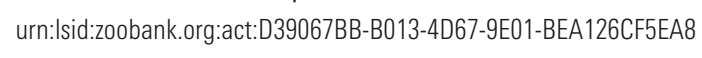 (Figs 9, 17)}

Type series: Holotype: $\sigma^{\star}$, C. VIETNAM: Kon Tum dist nr. Ngoe Thinh MAY. 2010. (NSMT). Paratypes: $1 \sigma^{*}$, the same data as for the holotype (MFPC); $10^{\star}$, C. VIETNAM: Kon Tum Province, ca. $30 \mathrm{~km}$ from Kon Plong,

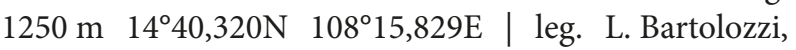
A. Bandinelli, S. Bambi, V. Sbordoni at light 4-7.V.2016 (nMag. 3078) (MZUF).

Description: Body shape elongate ovoid, weakly convex; body length: 14.7-15.7 mm, width: 8.8-9.0 $\mathrm{mm}$.

Color. Dorsal surface light green with metallic shine, elytra with brown suffusions; pronotum with narrow yellow band along lateral margins; front of clypeus and antennae yellowish brown; ventral surface and legs yellowish brown with weak metallic reflections except for mesotarsi, metatibia and -tarsi (greenish to reddish copper) and abdominal ventrites (reddish brown).

Head with erect yellowish brown setae $(0.07-0.38 \mathrm{~mm}$ in length) becoming sparser and shorter anteriad, longer and denser latero-posteriad; interocular distance equals 0.65 times the maximum transverse head width. Antennal club 0.9 times as long as footstalk. Clypeus semicircular, finely and densely rugoso-punctate; anterior margin distinctly reflexed; fronto-clypeal suture almost straight. Frons densely and coarsely rugoso-punctate anteriorly and in the middle, punctures becoming sparser and smaller in postero-lateral portions. Vertex coarsely punctate, the punctures somewhat sparser laterad.

Pronotum 1.6 times as wide as long; sides arcuate in the middle, subparallel basad, nearly straight and strongly convergent anteriorly; widest at base; lateral marginal line almost reaching the hind angles; basal marginal line missing; front angles produced and acute, hind angles obtuse, slightly rounded off; surface evenly covered with moderately large, moderately dense, round to weakly transverse punctures; punctures smaller laterad; each puncture bearing an erect yellow seta (0.15-0.4 mm in length).

Scutellum 1.6 times as wide as long; apex rounded; punctures like those of disc of pronotum.

Elytra. Regularly striate-sulcate; intervals weakly convex; each stria marked by a regular line of almost round, hairless punctures; entire surface covered with transverse, seta-bearing (0.05-0.15 $\mathrm{mm}$ in length) punctures; this irregular punctation sparser on two inner primary costae as well as on the two secondary costae formed within the subsutural interstice; epipleura disappearing shortly before apical curvature which is fringed by thick erect setae; marginal membrane starting near middle of metacoxa.

Pygidium triangular, widely rounded at apex; weakly tumid; disc with reticulate striolation which is arranged concentrically around the tumidity; with rather dense yellow setosity (0.1-0.75 $\mathrm{mm}$ in length), setae longer in the apical portion. 

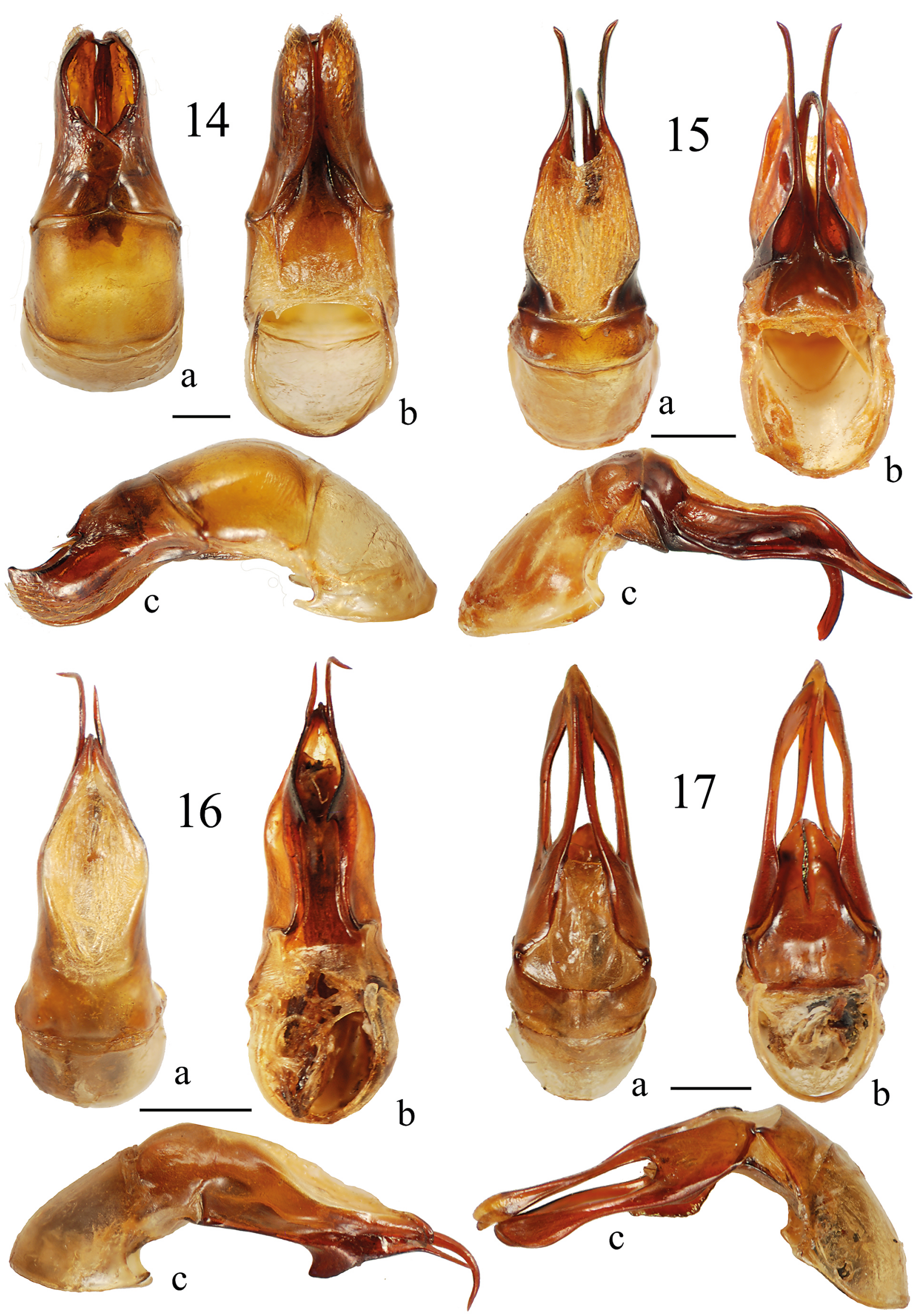

Figs 14-17: Anomala spp., aedeagus dorsal (a), ventral (b) and lateral (c). - 14. A. ordinata spec. nov., holotype. 15. A. recordata spec. nov., holotype. 16. A. asaitoae spec. nov., holotype. 17. A. herbacea spec. nov., holotype. Scale =1 mm. 
Mesoventrite very narrow and somewhat concave between the approximated mesocoxae.

Metaventrite with very dense, partly transversely confluent punctures at the sides, sparsely punctate, almost smooth in the middle; with dense, long, pale yellowish brown setae (0.13-1.0 $\mathrm{mm}$ in length) at the sides which become sparser and shorter in the middle.

Abdominal ventrites with rather sparse, transverse punctures (somewhat denser at the sides); each ventrite with a transverse row of semierect yellow setae in the apical half (0.05-0.13 $\mathrm{mm}$ in length) and denser adpressed setosity laterally; sides of abdominal ventrites 1-4 distinctly carinate.

Legs slender and long; protibia bidentate; terminal tooth rather short, somewhat obtuse; protarsal segment 5 ventrally with a sharp tooth in middle; inner protarsal claw and outer mesotarsal claw apically incised; the upper branch of the inner protarsal claw small and slender, the lower branch broad, somewhat enlarged ventrally with obtuse tooth in the middle; the upper branch of outer mesotarsal claw slightly more slender than the lower one.

Diagnosis: This species is easily distinguished from all other known Anomala by the combination of a setose dorsal surface, a light metallic green dorsum and sulcate elytra. Furthermore, the shape of the aedeagus with its long, bifid parameres is unique (fig. 17). No described species seems to be closely related. Several species with dorsal setosity occur in China and Indo-China and were subsumed in the "hirsutula-group" (LIN, 1996). Anomala herbacea, however, does not fit in this group because the dorsal setosity is rather semi-erect to erect (adpressed to semi-erect in species of the hirsutula-group), the punctures of pronotum and elytra are less transverse, the propygidium is not exposed in A. herbacea, and the body is more depressed and broader than in all species of the hirsutula-group. In general, the dorsal setosity is a quantitative rather than a qualitative character in Anomala, because seta-bearing punctures on pronotum and elytra might be observed in many known species depending on magnification used.

Etymology: The species epithet is formed by the Latin adjective "herbaceus, -a, -um". It translates as "grassy" or "grass-colored". The name refers to the green, hairy dorsal surface of this species.

\section{Faunistic records}

\section{Anomala acutangula OHAUS, 1914}

Distribution: China, Vietnam.

Specimens examined: $30^{\star} o^{\star}, 1$ ㅇ, N-VIETNAM Cao Bang Prov. vic. Tinh Tuc, Nui Pia Oac Nature Reserve, 13.V.2014, 22 $35^{\circ} 50^{\prime \prime} \mathrm{N}, 105^{\circ} 52^{\prime} 21^{\prime \prime E}$ 900-1300 m leg. A. Skale (ASPC); 1 ๙ , N-VIETNAM Cao Bang prov., vic.
Vin Den, Nui Pia Oac NP, 06.-10.V.2013, 900-1300 m A. Skale leg. (ASPC); $40^{\star} o^{\star}$, Vietnam N, Vinh Phuc Pr. Tam Dao NP, 1000 m N: 21²7,577', E: 105³8,489 VIII. 2011, M. Pejcha lgt. (NME); $1 \sigma^{\star}$, Coll. I.R.Sc.N.B. China, Guangdong Nanjing N. P. 26.III.2003 Leg. P. Grootaert (RBINS).

Remarks: This species was described from Lào Cai in northwestern Vietnam and recently also found in additional localities in northern Vietnam, as well as in the province of Guangdong, China. The taxonomic relationship of this species to the very closely related A. rugulipennis LiN, 1999, A. nigrolineata KoвAYASHI, 1987 and A. opaconigra Frey, 1972 from China and Taiwan requires further study.

\section{Anomala aeneoprasina PROKOFIEV, 2013}

Distribution: Vietnam.

Specimens examined: $2 o^{x} o^{x}, 2$ 우, S Vietnam: Lam Dong Prov., Lac Duong Distr., Bidoup Nuiba Natl Park, surr Giang Ly Ranger Station | 1420-1460 m a.s.l. 16-21. VI.2015 at light | legit L. Bartolozzi (CZPC, MZUF); $50^{\star} o^{\star}, 5$ 우 온 Vietnam: Khanh Hoa Prov., Hon Ba Preserve, 1500 m. 12.120N, 108.948E, 12-15 June 2015, N. Schiff (PLPC).

Remarks: All collection records of this recently described species are from the type locality in southern Vietnam: Bidoup Núi Bà National Park and the Hòn Bà Nature Reserve in the province of Khánh Hòa.

\section{Anomala ahrensi ZoRN, 2011}

Distribution: Vietnam.

Specimens examined: $4 \sigma^{\star} o^{\star}, 19+9$, Sapa, N. Vietnam, 3 28-V-1993, N. Katsura leg. (MFPC); 1 ㅇ, N-Vietnam Lao Cai Prov., Hoanglien NP, Tram Ton, N22 21.20 E103ํ46.51, 1800-2050 m, 15.5.2015. leg. A. Weigel (NME); $10^{\star}$, Haiphong Viet-nam bor. lgt. Brož -1958.

Remarks: The record from Trạm Tôn in northern Vietnam represents the highest altitude at which this species has been collected.

\section{Anomala anguliceps ArRow, 1917}

Distribution: China, Laos, Myanmar, Thailand (new country record), Vietnam.

Specimens examined: $1 \sigma^{\star}, 2$ 우, 은.VIETNAM, Prov.

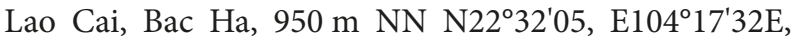
28.-30.V.1999, Ahrens, Jäger, Fabrici leg. (CZPC); $10^{\star}$, 
N. VIETNAM - Lao Cai prov., Van Ban dist. Van Ban Nature Reserve (at light) ( 1000 m) 23.-26.V.2011, L. Bartolozzi, S. Bambi, F. Fabiano, E. Orbach leg. (MZUF); 1 우, N-VIETNAM Bac Kan Prov. Ba Bè NP., (entry), 16-20.V.2014, 22 $2^{\circ} 25^{\prime} 07^{\prime \prime N}, 105^{\circ} 38^{\prime} 09^{\prime \prime E}$, 180-220 m, leg. A. Skale (ASPC); $10^{\star}$, N-VIETNAM Cao Bang prov., vic. Vin Den, Nui Pia Oac NP, 06.-10.V.2013, 900-1300 m A. Skale leg. (ASPC); 1 ㅇ, N-Vietnam Cao Bang Prov. vic. Tinh Tuc, Son Dong, Nui Pia Oac Nature Reserve, 9.-15.V.2014, 22 $37^{\prime} 55^{\prime \prime N}, 105^{\circ} 52^{\prime} 98^{\prime \prime} \mathrm{E}$ 850-1300 m leg. A. Skale (ASPC); $10^{\star}, 1$ ㅇ, C VIETNAM: Kon Tum Province, surroundings Kon Plong,

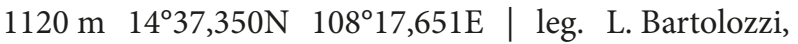
A. Bandinelli, S. Bambi, V. Sbordoni at light 4-7.V.2016 ( $n^{\circ}$ Mag. 3078) (CZPC, MZUF); $10^{\star}$, S VIETNAM 21.-27.4. Dalat City, 1994 P. Pacholátko \& L. Dembický leg. (CZPC); 12 ㅇ ㅇ, NE-LAOS Hua Phan prov.: Ban Saleui, Phou Pan (Mt.) 20²' $2^{\prime} \mathrm{N} 104^{\circ} 01^{\prime} \mathrm{E}$; 1300-1900 m 01.-31.V.2011; leg. C. Holzschuh Ankauf ZFMK Bonn 2011 (CZPC, ZFMK); 1 ơ, THAI 1-8.V.1993 SOPPONG PAI 1800 m Pacholátko \& Dembický leg. (CZPC); 1 , THAI-N. 1.-19.v.1998 Chiang Mai prov., Ban Sanpakia, 1400 m Ivo Martinů leg. (CZPC); 1 우, China, Yunnan Prov. E101'53'33" N2518'37" Lufeng (county) Gaofeng (village), $2200 \mathrm{~m}$ 09.-13. June 2013, lux leg. A. Kallies \& M. Owada (CZPC); 1 o $^{\star}, 1$ ㅇ, CHINA Yunnan 4.7.1990 $60 \mathrm{~km}$ SE Kunming Shilin D. Král lgt (CZPC); $10^{\star}$, CHINA: S-YUNNAN (Xishuangbanna) 37 km NW Jinghong GuoMen Shan NNNR | 22¹7.91N E100 38.85 leg. A. Weigel 20.V.2008, LF (CZPC).

Remarks: Anomala anguliceps, which was misidentified as A.siamensis (Nonfried, 1891) in PaUlian (1959), has a comparatively wide distribution, extending from the Karen Hills, Myanmar (Arrow 1917), to the Dalat Plateau in southern Vietnam, including large parts of Thailand, Laos and Vietnam, as well as southern Yunnan. There are two females in the CZPC from the Cardamom Mountains in Cambodia, which probably represent this species, but males are needed to confirm this record.

\section{Anomala atriventris ZoRN, 2011}

Distribution: Vietnam.

Specimens examined: $3 o^{x} o^{x}, 1+$, VIETNAM, Lao Cai Prov., Hoang Lien NP, Tram Ton, 1915 m, 22.3493723N, $103.7704565^{\circ} \mathrm{E}$, forest edge, at light, 8-11.IV.2010, leg. L. Papp, L. Peregovits \& Z. Soltész VN2010PL_4 (CZPC, HNHM).

Remarks: This species, known previously only from the holotype, was described from "Hoang Lien Son, Sa Pa", Vietnam. The additional specimens reported above were also collected close to the type locality. The labels on the new specimens, however, provided more accurate collecting data.

\section{Anomala aulax (WIEDEMANN, 1823)}

Distribution: China, Vietnam.

Specimens examined: $2 \sigma^{\top} \sigma^{\star}, 17$ 우 온, Tam Dao, N. Vietnam, 28 30-IV-1991, M. Fujioka \& R. Muramoto leg. (MFPC); 1 o $^{\star}, 1$ ㅇ, Mt. Tam Dao (LT: $900 \mathrm{~m}$ ) Vinh Phu Prov. [N-Vietnam] 12.v.2003, S. Nomura leg. (NSMT); $22 o^{*} o^{*}, 10$ 우 ㅇ, Tam Dao, Vinh-Phu prov., Vietnam, 30-IV 6-V-1996, Y. Okushima leg. (HKPC); 1 ㅇ, Mt. Tam Dao, N. Vietnam, 16.VI.1997, S. Nomura leg. (NSMT); 9 o $^{\star}$, 6 우 ㅇ, Sa Pa (LT: 1500 m), Lao Kai Prov. N. Vietnam, [22.V.1998] / [2.VI.1999] / [13.V.2000] / [14.V.2000] S. Nomura leg. (NSMT); 1 o , 2 우 ㅇ, Mt. Pia Oac (LT: 1250 m) Cao Bang Prov. N. Vietnam, 15.v.1999, S. Nomura leg. (NSMT); 4 o o $0^{\star}, 2$ 우 우 , Cao Bang, N. Vietnam, 5-VI-1996, Itoh leg. (MFPC); 1 ○, Mau Son, Lang Son Pr. Vietnam 25 VI - 2 VII 2011 leg. Do Manh Cung (KWPC); $10^{*}$, VIETNAM N, Lang Son Pr. Loc Binh,

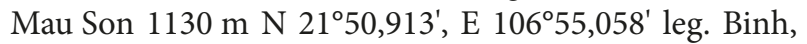
12-13.6.2016 (ASPC); $1 \sigma^{*}$, Wuyi Shan, Fujian, China, 14 29-VI-1982, Songun Tei leg. (MFPC); 1 ㅇ, Nankou, Fujian, China, 9 14-V-1982, Chiuka Riu leg. (MFPC); $3 o^{*} o^{x}, 5$ ㅇ 우, Longyon, Fujian, China, 15-V-1998. ChinKin Yu leg. (HKPC); $1 \sigma^{*}$, Chingcherng-shan, Fujian, China, 20-VII-1990, Chin-Kin Yu leg. (HKPC); $10^{\star}$, China. Sichuan Emei Co. Emei ShanJune 1993. Benes (CZPC); $10^{\star}$, China, Sichuan, Moxi $29^{\circ} 13 \mathrm{~N} 102^{\circ} 10 \mathrm{E}$, 1600 m 2.VII.1998, J. Schneider | J. Farkač, D. Král, J. Schneider \& A. Smetana (CZPC); $10^{\star}$, CHINASICHUAN Nanjiang 21.5.-23.5.2005 lgt. E. Kučera (CZPC); $2 \sigma^{\star} \sigma^{*}, 1$ ㅇ, CHINA, Guangxi A.R., 5.iv.2013 Shiwandashan National Forest Park (forested river valley, at light) $21^{\circ} 54.4^{\prime} \mathrm{N}, 107^{\circ} 54.2^{\prime} \mathrm{E}, 290-360 \mathrm{~m}$ M. Fikáček, J. Hájek, J. Růžička leg. (NMPC); $20^{\star} o^{\star}, 1$ ㅇ, CHINA, Guangdong prov. Nanling National Nature Reserve Dadongshan, 18-21.iv.2013 (border of mixed forest, at light) $24^{\circ} 56.0^{\prime} \mathrm{N}, 112^{\circ} 42.9^{\prime} \mathrm{E}, 690 \mathrm{~m}$ J. Hájek \& J. Růžička leg. (NMPC); 2 우, SE China, Guangdong Prov. Shaoguan Distr., Nanling Mts Nature Res. Guest house

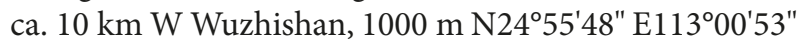
2.-6.VII.2012 lux leg. A. Kallies \& Y. Arita (CZPC); $1 \mathrm{o}^{\star}$, Nanling Mts. (900-1400 m) Shaoguan, Guangdong [S-China] 16-20.v.2009 Y.Kishida \& M. Wang leg. (NSMT); 1 , CHINA GUIZHOU Env. Kaili, Xijiang $\mathrm{h}=1200 \mathrm{~m} \mathrm{14.06.2000} \mathrm{leg.} \mathrm{S.} \mathrm{Murzin} \mathrm{(CZPC);} 1 \mathrm{o}^{\star}$, Hongkong New Territories Seikung 14.4.78 leg. A. Poll (ARPC); 1 ㅇ, CHINA Wuy Shan Jiangxi-Fujian border 50 km SE Yingtau 1600 m, V 2002 (ARPC).

Remarks: Anomala aulax is widespread in China (ZoRN \& BEZDĚK, 2016) and has been collected in several localities in northern Vietnam. The extent of its distribution, however, is poorly known. There seem to be some variation concerning color and aedeagus shape across its distribution range. Whether or not this is taxonomically relevant is yet unclear. 


\section{Anomala bedeli OHAUs, 1914}

Distribution: China, Laos, Thailand (new country record), Vietnam.

Specimens examined: $1 \sigma^{\top}$, Vietnam - N (Na Hang) 160 km NNW Ha Noi, NE env. Na Hang, 1-14.06.1996,

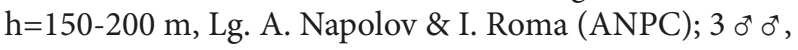
1 오 Vietnam-N, Lao Cai Prov., Hoang Lien Son Nat. Res., Sa Pa vill. env., 27.5.-2.6.1998, Lg. A. Napolov | $22^{\circ}$ $20^{\prime} \mathrm{N} 103^{\circ} 50^{\prime} \mathrm{E} h=1250 \mathrm{~m}$ (ANPC); $10^{\prime}, 1$ 우, N. Vietnam SA PA env. LAO CAI prov. $22^{\circ} 19^{\prime} 52^{\prime \prime N} 103^{\circ} 50^{\prime} 35^{\prime \prime} \mathrm{E}$ 23.-27.v.1999 1630-1680 m leg. Fabrici, Jaeger, Ahrens (CZPC); $10^{\star}$, LAOS $21^{\circ} 09^{\prime} \mathrm{N} 101^{\circ} 19^{\prime} \mathrm{E}$ Louangnamtha pr. Namtha-MuangSing 5-31.v.1997. 900 Vit Kuban leg. $1200 \mathrm{~m}$ (PPPC); 1 o , LAOS Naka 1.V.1998 leg. Strba (CZPC); $60^{\star} o^{\star}$, NE-LAOS Hua Phan prov.: Ban Saleui, Phou Pan (Mt.) $\sim 20^{\circ} 12^{\prime} \mathrm{N} \quad 104^{\circ} 01^{\prime} \mathrm{E} ; 1300-1900 \mathrm{~m}$ 01.-31.V.2011; leg. C. Holzschuh Ankauf ZFMK Bonn 2011 (CZPC, ZFMK); $10^{\star}$, LAOS-NE; HUA PHAN prov. BAN SALUEI; Phu Phan Mt.: $20^{\circ} 15^{\prime} \mathrm{N} 104^{\circ} 02^{\prime} \mathrm{E}$; 1500-2000 m; 26.iv.-11.v.2001 J. Bezděk \& D. Hauck leg. (CZPC); $10^{\star}$, LAOS-N; Xieng Khuang prov. Nong Haet $19^{\circ} 30^{\prime} \mathrm{N} 104^{\circ} 03^{\prime} \mathrm{E} ; 29 .-31 . v .2001$ J. Bezděk leg. (CZPC); $10^{\star}$, NW THAILAND, 1.-23.5. Mae Hong Son, 1991 Ban Huai Po, 1600-2000 m J. Horak leg. (CZPC); $20^{\star}$ o $^{\star}, 1$ 우,

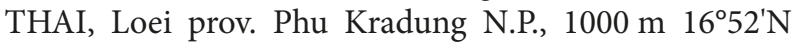
1014'ㄹ 16-1.v.1999, D. Hauck leg. (CZPC); 1 ㅇ, THAI,

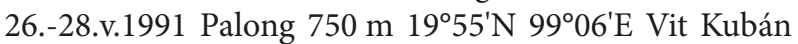
leg. Thailand '91 Thanon Thong Chai D. Král \&

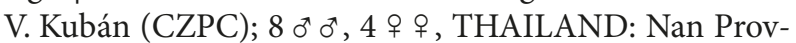
ince Amphur Bo Kluea; Tumbon Phufa; Doi Phuka Park ranger station 621 . April 2003; L-473 | $19^{\circ} 01^{\prime} \mathrm{N} 101^{\circ} 11^{\prime} \mathrm{E}$ 538 m UV pan trap colls: Vitheepradit, Prommi \& Setaphan (CZPC, PLPC, UMO); $10^{\star}$, Guizhou, Ceheng, Weinan 800-950 m, 1979.V.23-27 leg. Du Shaokun (GEI).

Remarks: Anomala bedeli was incorrectly synonymized with A. holcoptera Fairmaire, 1889 by Paulian (1959) (ZorN, 2005) and subsequently reported under this name from the southern Chinese provinces Guizhou and Yunnan in Lin (1992). The record "Anhui" in ZoRN (2006) and ZORN \& BEZDĚK (2016) is incorrect because it was based on incorrectly labeled material. Additionally, the species occurs in northern Thailand, Laos and Vietnam.

\section{Anomala chloropus chloropus ArRow, 1917}

Distribution: India, Laos (new country record), Myanmar, Thailand (new country record), Vietnam (new country record).

Specimens examined: $1 \sigma^{x}, \mathrm{~N}$. VIETNAM, Umg. Tam Dao, Mt. VII 2008 local collectors legt. (CZPC); $20^{\star} \sigma^{\star}$, 1 ㅇ, N-VIETNAM Bac Kan Prov. Ba Bè NP., (entry), 16-20.V.2014, $22^{\circ} 25^{\prime} 07^{\prime \prime N}, 105^{\circ} 38^{\prime} 09^{\prime E}, 180-220 \mathrm{~m}$, leg.
A. Skale (ASPC, CZPC); 1 ơ, N. VIETNAM - Lao Cai province, Van Ban district: Khanh Yen City 22.V.2011| L. Bartolozzi, S. Bambi, F. Fabiano, E. Orbach leg. (Num. Magazzino 2909) (MZUF); $3 \sigma^{\star} \sigma^{\star}$, NORTH THAILAND MAE TAMAN 25.6.-04.07.1998 50 km NW CHIANG MAI lgt E. Kučera (CZPC); $6 \sigma^{*}$, THAILAND Chiang Dao Hill Resort 100 km N Chiang Mai, $650 \mathrm{~m}$ 11.-16.VIII.2009 S. Murzin leg. (CZPC); $10^{\star}$, THAILAND Phrae Prov., Wang Chin 160 m, 22.08.2012 leg. R. Ohnesorge (ASPC); 1 ơ, LAOS Naka 1.V.1998 leg. Strba (CZPC).

Remarks: Anomala chloropus seems to be a very widespread species in Southeast Asia with a distribution range extending from northeastern India (CHANDRA \& GUPTA 2012) to southern Vietnam, from which the subspecies codorensis Prokofiev, 1915 was described (Con Dao Island). Here, we report the nominate subspecies from Laos, Thailand and Vietnam for the first time. Whether or not the very similar species A. dentifera LIN, 2002 from southeastern China is really a different taxon is not yet clear and requires additional study.

\section{Anomala coxalis BATES, 1891}

Distribution: China, Vietnam.

Specimens examined: $1 \sigma^{*}, 10$ 우, N.-Vietnam, Bac Giang Prov. Tay Yen Tu Nat. Res. Thanh So'n N2 ${ }^{\circ} 12.812$ E1064․846 $86 \mathrm{~m}$ 18.05.-21.05.2015, leg. A. Skale (ASPC); $2 \sigma^{\star} \sigma^{*}, 1$ 오 N VIETNAM - Bac Kan province, Ba Be National Park ( 350 m) (at light) 3-8.VI.2011 | L. Bartolozzi, S. Bambi, F. Fabiano, E. Orbach leg. (Num Magazzino 2909) (MZUF); 7 o $^{\star}, 3$ 우 으, N-VIETNAM Bac Kan Prov. Ba Bè NP., (entry), 16-20.V.2014, $22^{\circ} 25^{\prime} 07^{\prime \prime} \mathrm{N}, 105^{\circ} 38^{\prime} 09^{\prime \prime E}, 180-220 \mathrm{~m}$, leg. A. Skale (ASPC, CZPC); $1 \sigma^{\star}$, N.VIETNAM (TONKIN) TAMDAO 12.-24.5.1989 PACHLATKO Leg. (PPPC).

Remarks: Anomala coxalis is widespread in China (ZoRN \& BEZDĚK 2016) and is known from some localities in northeastern Vietnam (PAULIAN 1959). Our new data suggest that this species is more widely distributed in northern Vietnam than previously known.

\section{Anomala curator BENDERITTER, 1929}

Distribution: Cambodia (new country record), Thailand (new country record), Vietnam.

Specimens examined: $1 \sigma^{\star}$, Chiang Mai Prov., Chiang Dao N.P., Nam Tok Srisongwan, $600 \mathrm{~m}$, mr vapor lt., 17 March 2002, Robert Sites. (PLPC); 1 ㅇ, THAILAND: Phrae Province Wieng Ko Sai N.P.; $350 \mathrm{~m}$ $17^{\circ} 58^{\prime} \mathrm{N} 99^{\circ} 35^{\prime} \mathrm{E} ; 29$ III 2003 pan UV light trap; L-425 Sites, Vitheepradit, Prommi (CZPC); 1 \% , Kamphaeng 
Phet Prov. ; Khlong Lan NP; UV pan trap 6. April 2003; L-450 | $16^{\circ} 07^{\prime} \mathrm{N} 99^{\circ} 16^{\prime} \mathrm{E}$ Sites, Vitheepradit, Prommi \& Setaphan (PLPC); $20^{\star} o^{\star}$, CAMBODIA Cardamom Mts. near Pramuoy village, $270 \mathrm{~m} 12^{\circ} 16^{\prime} \mathrm{N} 103^{\circ} 01^{\prime} \mathrm{E}$, Dry Dipterocarp/Gallery Forest 25.II.00, leg. M. Nuss (CZPC); CAMBODIA Cardamom Mts. near Cham Kar Chhrey $12^{\circ} 20^{\prime} \mathrm{N} 103^{\circ} 01^{\prime} \mathrm{E}, 350 \mathrm{~m}$, Dry Riverine in evergreen forest, 6.III.00, leg. M. Nuss (CZPC).

Remarks: Described from Quảng Trị in Central Vietnam, this species also occurs in Thailand and Cambodia, suggesting a wider distribution in southeast Asia.

\section{Anomala cyanipennis LIN, 1999}

Distribution: China, Laos (new country record), Vietnam (new country record).

Specimens examined: $1 \sigma^{\star}, 1$ 우 N. VIET NAM (Tonkin) pr. Hoang Lien Son SA PA 11.-15.V.1990 P. Pacholátko leg. (CZPC, PPPC); 6 o $^{\star}$ o $^{\star}, 10$ 우 오, NE-LAOS Hua Phan prov.: Ban Saleui, Phou Pan (Mt.) $\sim 20^{\circ} 12^{\prime} \mathrm{N} 104^{\circ} 01^{\prime} \mathrm{E}$; 1300-1900 m 01.-31.V.2011; leg. C. Holzschuh Ankauf ZFMK Bonn 2011 (CZPC, ZFMK).

Remarks: This species was previously only known from the type locality (Xishuangbanna, China). Our data confirm its occurrence in northwestern Vietnam, as well as in northern Laos.

\section{Anomala dalatensis FreY, 1971}

Specimens examined: Holotype: $\sigma^{\star}$, Dalat, 1966 S. Vietnam | TYPE | Type Anomala dalatensis n. sp. det. G. Frey, 1970 (NMBS). Additional material: $2 o^{\top} o^{\top}, 1$ 운, Vietnam: Lam Dong Prov. Bi Doup Nat. Park 12.182N, 108.680E, 1456 m. 6-10 June 2015, N. Schiff; 10 o $^{\top}$, 10 우 오, S VIETNAM, $12.03 \mathrm{~N} 108.27 \mathrm{E} 12 \mathrm{~km}$ N Dalat - Lang Bian 1580-1750 m, 17-21.iv.1995 Pacholátko \& Dembický (CZPC, PPPC).

Remarks: This species, known previously only from the holotype, was described from "Dalat", southern Vietnam. The additional specimens reported above were also collected close to the type locality. The labels on the new specimens, however, provided more accurate collecting data.

\section{Anomala delavayi FalRMAIRE, 1886}

Distribution: China, Laos (new country record), Myanmar, Vietnam (new country record).

Specimens examined: $20^{\star} 0^{\star}$, N-Vietnam Fan Si Pan near Sapa, 1500-1950 m 17.-30.VI.1999 A. Kallies leg.
(CZPC); $20^{\star} 0^{\star}, 7$ 우 우, N. Vietnam SA PA env. LAO CAI prov. 22¹9'52"N 10350'35"E 23.-27.v.1999 1630-1680 m leg. Fabrici, Jaeger, Ahrens (CZPC); 16 ơ $^{\top}, 17$ 우 우, Sapa, N. Vietnam, 3 28-V-1993, N. Katsura leg. (MFPC); $10^{*}$, Xiengkouang Laos 1996 (KWPC); $90^{*} o^{\star}, 10$ 우 우, LAOS-NE; HUA PHAN prov. BAN SALUEI; Phu Phan Mt.: $20^{\circ} 15^{\prime} \mathrm{N} \quad 104^{\circ} 02^{\prime} \mathrm{E} ; 1500-2000 \mathrm{~m}$; 26.iv.-11.v.2001 J. Bezděk \& D. Hauck leg. (CZPC); $120^{\star} 0^{\star}, 17$ 우, NE-LAOS Hua Phan prov.: Ban Saleui, Phou Pan (Mt.) $\sim 20^{\circ} 12^{\prime} \mathrm{N} \quad 104^{\circ} 01^{\prime} \mathrm{E} ; \quad 1300-1900 \mathrm{~m}$ 01.-31.V.2011; leg. C. Holzschuh Ankauf ZFMK Bonn 2011 (CZPC, ZFMK); 1 o, CHINA-YUNNAN 28.5.-9.6.1994 DALI lgt. Kučera (CZPC); 1 o , CHINA, YUNNAN DALI 1-7.VI.1994 leg. B. Siska \& T. Spevar (CZPC); $10^{\star}$, CHINA: S-YUNNAN (Xishuangbanna) $45 \mathrm{~km}$ SW Jinghong, vic. Bangzhang v ill. | N214'ㄱ' E100²7'02" 16-1700 m, 03.-05.V.2009 leg. A. Weigel, blüh. Cast. (NME).

Remarks: This species was known previously only from China (Yunnan) (FaIrmaire 1886, Frey 1972, Prokofiev 2013c) and Myanmar (Arrow 1917). Our records extend that range into Laos (Xieng Khouang and Hua Phan provinces) and northwestern Vietnam (Lào Cai province).

\section{Anomala densa ArRow, 1917}

Distribution: Cambodia (new country record), China, Laos (new country record), Myanmar, Thailand, Vietnam.

Specimens examined: $10^{*}, 2 \circ \circ$, Vietnam NP Cat Tien Nam Cat Tien, Tan Phu co. Dong Nai $11^{\circ} 25.609^{\prime} \mathrm{N}$ $107^{\circ} 26.074^{\prime} \mathrm{E}, 136 \mathrm{~m}$ XII. 2014, Hoa Binh legt. (CZPC); $1 \mathrm{o}^{*}$, LAOS centr 27.IV.-1.V.1997. $70 \mathrm{~km}$ NE Vientiane, BAN PHABAT env., $150 \mathrm{~m} \mathrm{~N} 18^{\circ} 16.1^{\prime}$ E $103^{\circ} 10.9^{\prime}$ E. M. Strba \& M. Hergovits leg. (CZPC); 1 ㅇ, LAOS, Luangphabang province Mt. Phou Phakhao, Namtap vill. June 7-11, 2009, local collector (CZPC); $20^{-\top} o^{-1}$, LAOS Ban Na Hin 15.-21.5.2007 B. Makovsky lgt. (CZPC); $7 o^{\star} o^{*}, 14$ ㅇ 우, Thailand 10/89 $25 \mathrm{~km}$ NW Lansak $110 \mathrm{~m}$, leg. Thielen (CZPC); 2 ㅇ ㅇ, Thailand 14-21.iii.1996 Chumphon prov. Pha To env. $9^{\circ} 48^{\prime} 98^{\circ} 47^{\prime}$ P. Prudek leg. (CZPC); 5 우, THAILAND: Phang Nga Prov. Sri Phang Nga NP Tam Nang Waterfall; $68 \mathrm{~m} 08^{\circ} 58^{\prime} \mathrm{N} 98^{\circ} 27^{\prime} \mathrm{E}$; L-792 pan light trap; 24. May 2005 Sites, Vitheepradit \& Prommi (PLPC, UMO); 1 \& , Thailand bor. Fang Tha Ton 26.5.1997 Lgt. M. Snizek (CZPC); $10^{\star}$, N. Thailand, Khon Kaen Prov. Si Chom Phu, 220 m, 16 $6^{\circ} 8531$ N, 102 2526 E R. Ohnesorge VI.2012 (ASPC); $10^{\star}$, THAILAND: Phrae

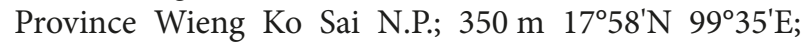
29 III 2003 pan UV light trap; L-425 Sites, Vitheepradit, Prommi (PLPC); 2 + , THAILAND: Saraburi Prov.; Khao Yai National Park, Park hdqtrs; 27 March 2008 coll: R.W. Sites (PLPC); 1 오 , Cambodia Sihanouk-ville, Thailand Gulf, Kaoh Rung Isl. $10^{\circ} 48^{\prime} \mathrm{N} 103^{\circ} 11^{\prime} \mathrm{E}$ 5.-10. III.02 V. Murzin leg. (CZPC); 1 ○ , 1 ค, Cambodia $15 \mathrm{~km}$ 


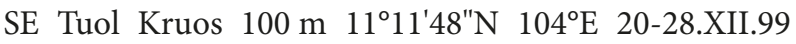
M. \& S. Murzin leg. (CZPC); 2 우, CAMBODIA Cardamon Mts. near Pramuoy village, $270 \mathrm{~m} 12^{\circ} 16^{\prime} \mathrm{N} 103^{\circ} 01^{\prime} \mathrm{E}$, Dry Dipterocarp/Gallery Forest, 25.02.00, leg. M. Nuss (CZPC); 3 ㅇ ㅇ , Cambodia, Trapaeng Rung 80 km SE Koh Khong Murzin 20.-29.XII.2008 (CZPC).

Remarks: Anomala densa seems to be a widespread species in mainland Southeast Asia, inhabiting a large part of the Indochinese Peninsula (Paulian 1959, Prokofiev 2014). Here, we report this species for the first time from Laos and Cambodia.

\section{Anomala esmeralda ProKofiev, 2013}

Distribution: Vietnam.

Specimens examined: $10^{\star}, 2$ 우, C VIETNAM: Gia Lai Province, Kon Chu Rang Nature Reserve, surroundings HQ, about $900 \mathrm{~m} \mathrm{14} 4^{\circ} 28,450 \mathrm{~N} \mathrm{108} 32,401 \mathrm{E}$ | leg. L. Bartolozzi, A. Bandinelli, S. Bambi, V. Sbordoni at light 8-12.V.2016 (nMag. 3078) (CZPC, MZUF); 1 o , 1 우, C VIETNAM: Gia Lai Province, Kon Chu Rang Nature

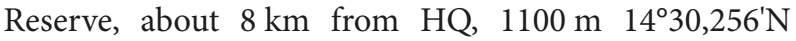
$108^{\circ} 30,109 \mathrm{E} \mid$ leg. L. Bartolozzi, A. Bandinelli, S. Bambi, V. Sbordoni at light 8-12.V.2016 ( $n^{\circ}$ Mag. 3078) (MZUF); $30^{\top} o^{\star}, 1$ ㅇ , C. VIETNAM: Gia Lai Province, Kon Chu Rang

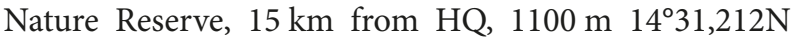
$108^{\circ} 28,192 \mathrm{E} \mid$ leg. L. Bartolozzi, A. Bandinelli, S. Bambi, V. Sbordoni at light 8-12.V.2016 (n Mag. 3078) (CZPC, MZUF); 1 ㅇ, C VIETNAM: Kon Tum Province, ca. 30 km from Kon Plong, $1250 \mathrm{~m} \mathrm{14}{ }^{\circ} 40,320 \mathrm{~N} 108^{\circ} 15,829 \mathrm{E}$ | leg. L. Bartolozzi, A. Bandinelli, S. Bambi, V. Sbordoni at light 4-7.V.2016 (nºga. 3078) (MZUF).

Remarks: Anomala esmeralda was known only from Khánh Hòa and Lâm Đông provinces in southern Vietnam. Our records extend its range to two additional localities in central Vietnam (Gia Lai and Kon Tum provinces).

\section{Anomala flavoguttata MiYAKE, 2000}

Distribution: China (new country record), Vietnam.

Specimens examined: 1 , N. VIETNAM - Lao Cai prov. Hoang Lien NP, surr. Sa Pa pass, at light ( 1900 m) 27.V.-2.VI.2011, L. Bartolozzi, S. Bambi, F. Fabiano, E. Orbach leg. (CZPC); $20^{\star} o^{\star}, 1$, VIETNAM, Lao Cai Prov., Hoang Lien NP, Tram Ton, 1915 m, $22.3493723^{\circ} \mathrm{N}$, $103.7704565^{\circ} \mathrm{E}$, forest edge, at light, 8-11.IV.2010, leg. L. Papp, L. Peregovits \& Z. Soltész VN2010PL_4 (CZPC, HNHM); $1 \sigma^{\star}$, Yunnan, Dawei Mount, hotel at hilltop, Pingbian, 2014/5/25-30, Mao Ye leg. (WFPC) (examined by photographs); 1 đ, Yunnan, Hong Qi Reservoir, Pingbian, Dawei Mount, foothills, 2016/5/20, Lu Qiu leg. (WFPC) (examined by photographs).
Remarks: Only the holotype of Anomala flavoguttata was known previously. The recently discovered specimens reported above were collected near the type locality, and they provide more precise locality data. Moreover, this apparently rare species is also known from the Dawei Mountain Nature Reserve, Yunnan, China.

\section{Anomala fuscosignata OHAUS, 1905}

Distribution: China (new country record), Vietnam.

Specimens examined: $1 \sigma^{\star}$, Tonkin Montes Mauson April, Mai 2-3000' H. Fruhstorfer (CZPC); $10^{\star}$, Damingshan Mts. Wuming City. Guangxi Prov. 2014-VI-2 C. Li legs. (ZMPC).

Remarks: To date, Anomala fuscosignata was known only from the series collected by Hans Fruhstorfer on Mt. Mẫu Sơn (Lang Sơn Province, North Vietnam) early in the $20^{\text {th }}$ century. Despite extensive recent field work in northern Vietnam, this species has not been found again. Recently, Zhao Mingzhi (Guangzhou) kindly provided detailed photographs of a specimen collected at Daming Shan (Guangxi) that turned out to be this rare species.

\section{Anomala gemelloprasina ProKofiev, 2015}

Distribution: Vietnam.

Specimens examined: $1 \sigma^{\star}, 3$ $~+$, Mt. Bach Ma, T. T. Hue prov. C. Vietnam, 5.v.[7.v.]2003, Nomura leg. (NSMT); 1 ㅇ, Mt. Bach Ma, Thua Thien Hue Prov. [C. Vietnam], 7-vi-2002, S.Nomura leg. (NSMT); 1 †, C-VIETNAM Tua Thien Hue Prov. Bach Ma Natl. Park, surr. Hotel Morin (1350-1400 m), $16,2^{\circ} \mathrm{N} 107,85^{\circ} \mathrm{E} 23-28 . V .2014$ (at light) / legit L. Bartolozzi, G. Chelazzi, A. Bandinelli, S. Bambi, F. Fabiano ( ${ }^{\circ}$ Magazz. 2978) (MZUF); $5 \sigma^{\top} \sigma^{\star}, 3$ 우 우, C VIETNAM: Thua Thien-Hue Prov., Bach Ma National Park $\left(16.193^{\circ} \mathrm{N} 107.853^{\circ} \mathrm{E}\right) 1250 \mathrm{~m}$ | 28.V.-1.VI.2017 L. Bartolozzi, E. Orbach, V. Sbordoni, S. Bambi \& A. Bandinelli leg. (numero Mag. 3089) (CZPC, MZUF); $3 o^{\star} o^{\star}, 5$ 우 우, C VIETNAM: Kon Tum Province, surround-

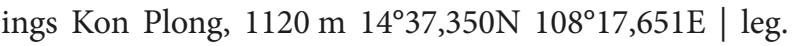
L. Bartolozzi, A. Bandinelli, S. Bambi, V. Sbordoni at light 4-7.V.2016 (nMag. 3078) (CZPC, MZUF); 1 ㅇ, C VIETNAM: Gia Lai Province, Kon Chu Rang Nature Reserve, surroundings HQ, about $900 \mathrm{~m} \mathrm{14}{ }^{\circ} 28,450 \mathrm{~N} \mathrm{108} 32,401 \mathrm{E}$ | leg. L. Bartolozzi, A. Bandinelli, S. Bambi, V. Sbordoni at light 8-12.V.2016 (nMag. 3078) (MZUF); 1 ơ, Vietnam: Khanh Hoa Prov., Hon Ba Preserve, 1500 m. 12.120N, 108.948E, 12-15 June 2015, N. Schiff (PLPC).

Remarks: Including our new data, this recently described species is now known from the following Vietnamese provinces: Gia Lai, Khánh Hòa, Kon Tum, Lâm Đông, Thừa Thiên-Huế. 


\section{Anomala graminea OHAUs, 1905}

Distribution: China, Vietnam.

Specimens examined: $10^{\top}, \mathrm{N}$ Vietnam 1986 prov. Vinh phu Tam dao 27.5.-2.6.V. Svihla lgt. (CZPC); $10^{\star}$, S CHINA NE-Guangxi Mao'ErShan 500 m VI-2009 lgt. Sehnal Häckel (CZPC); $10^{\star}$, Shanghai Ningpo |China Xanthus | 305508 (HNHM).

Anomala graminea is known only from southeastern China (ZORN \& BEZDĚK 2016) and the northeastern tip of Vietnam. The record above is the first for the Chinese province of Zhejiang.

\section{Anomala granuliformis LIN, 1996}

Distribution: China, Thailand, Vietnam (new country record).

Specimens examined: $1 \sigma^{*}, 1 \%$ N-VIETNAM Thai Nguyen Prov., Ngoc Thanh, Me Linh (IEBR station, 12.V.2012, $21^{\circ} 23^{\prime} 3^{\prime \prime N}, 105^{\circ} 42^{\prime} 44^{\prime \prime E}$, leg. A. Skale (KL/KF) (ASPC); $10^{\star}$, Burma/Thailand -border Mae-Sai Bacovsky lgt. 5.7.96 (CZPC); 1 ð, THAILAND Chiang Mai Prov. Doi Inthanon NP; Nam Mae Pan at Ban Mae Pan Noi; blacklicht trap $750 \mathrm{~m} ; 18^{\circ} 31^{\prime} \mathrm{N} 98^{\circ} 25^{\prime} \mathrm{E} 8-9$ June 2002 coll. P. Thamasenanupap (PLPC).

Remarks: Formerly known only from Yunnan, China, and northern Thailand (LIN, 1996b), this species was recently discovered in northern Vietnam. Because of the scattered records, the overall range of this species is yet unclear.

\section{Anomala harpagophysa Prokofiev, 2014}

Distribution: China (new country record), Vietnam.

Specimens examined: $1 \sigma^{*}$, Mt. Tam Dao, Vinh Phu prov., N. Vietnam, V-2008, native collector leg. (MFPC); 1 ㅇ, Cao Bang, N. Vietnam, V-1999, native collector leg. (MFPC); 1 ㅇ, Cao Bang, N. Vietnam, 5-VII-1996, Itoh leg. (MFPC); 1 ๙ , Tamdao Near Hanoi VIETNAM 3 - 8 VI 1990 leg. Masao Ito | K.WADA Col No. 519 (KWPC); 1 ․ Mt. Tam Dao (LT: 900 m), Vinh Phu prov., N. Vietnam, 6.V.2000, S. Nomura leg. (KWPC); 2 우 오. Mt. Deo Tram (LT: $1850 \mathrm{~m}$ ), nr. Sa Pa, Lao Cai prov., N. Vietnam, 14 15.V.1994, S. Nomura leg. (NSMT); 1 \% , Mt. Pia Oac, Cao Bang prov., N. Vietnam, v.1999, native collector leg. (NSMT); 1 , Mt. Pia Oac, Cao Bang, N. Vietnam, 22 29.v.1998, Haruki Karube leg. (MFPC); 1 ㅇ, Tam Dao, N. Vietnam, V-1994, native collector leg. (MFPC); 1 क , Cao Bang, N. Vietnam, v.1999, native collector leg. (MFPC); 1 o , 1 ㅇ, CHINA, GUIZHOU env. Kaili, Xijiang $h=1200$ m 14.VI.2000. leg. S. Murzin (CZPC); 1 đ , Guangxi, Wuming, Daming
Shan, lgt. Liu Sikong, 1963.V.21. (GEI) (examined by photographs only).

Remarks: This species was recently described from Mt. Mẫu Sơn from historical material collected by H. Fruhstorfer near the beginning of the 20th century. Recent findings suggest that its distribution range encompasses northeastern Vietnam and the neighboring Chinese province of Guangxi.

\section{Anomala imperialis Arrow, 1899}

Distribution: China, Laos (new country record), Vietnam.

Specimens examined: $1 \sigma^{\star}, \mathrm{N}$ VIETNAM (Tonkin) pr. Hoang Lien Son SA PA 11.-15.V.1990 P. Pacholátko leg. (CZPC); $10^{\star}$, Tam Dao, Vinh Phu Prov., N. Vietnam, $\mathrm{V}-2007$, native collector leg. (MFPC); $4 \sigma^{\star} \sigma^{*}, 14$ 우 ㅇ, Tam Dao, Vinh-Phu, Vietnam, 30-IV 6-V-1996, Y. Okushima leg. (HKPC); 1 \% , Mt. Tam Dao (LT: 900-950 m), Vinh Phu prov., N. Vietnam, 14 18.V.1999, S. Nomura leg. (NSMT); 1 ㅇ, Mt. Tam Dao, Vinh Phu prov., N. Vietnam, 3 5.V.1994, Haruki Karube leg. (KWPC); $10^{*}$, Mt. Tam Dao, Vinh Phu prov., N. Vietnam, V-VI.1993, Haruki Karube leg. (KWPC); $10^{\star}, \mathrm{N}-$ Vietnam Vinh Phuc Prov. Mt. Mo Qua. 03.V.2013 22³4'41"N 105² $52^{\prime} 48^{\prime \prime} \mathrm{E}$ 700-1000 m, leg. A. Skale (ASPC); $110^{\top} o^{\star}, 21$ 우 우, NE-LAOS Hua Phan prov.: Ban Saleui, Phou Pan (Mt.) $\sim 20^{\circ} 12^{\prime} \mathrm{N} 104^{\circ} 01^{\prime} \mathrm{E} ; 1300-1900 \mathrm{~m}$ 01.-31.V.2011; leg. C. Holzschuh Ankauf ZFMK Bonn 2011 (CZPC, ZFMK); 1 \%, CHINA, Guangxi A.R., 5.iv.2013 Shiwandashan National Forest Park (forested river valley, at light) $21^{\circ} 54.4^{\prime} \mathrm{N}, \quad 107^{\circ} 54.2^{\prime} \mathrm{E}, \quad 290-360 \mathrm{~m}$ M. Fikáček,

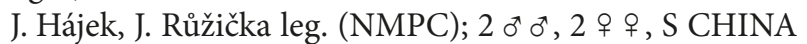
NE-Guangxi Mao'ErShan 500 m VI-2009 lgt. Sehnal \& Häckel (CZPC); $10^{\star}$, Shanghai Ningpo |China Xanthus | 305508 (CZPC).

Remarks: The currently known distribution of this species encompasses northeastern Laos, northern Vietnam and southeastern China. The "Yunnan" record mentioned by ZoRN (2006) and ZoRN and BEZDĚK (2016) should be disregarded because it was based on material largely bearing false locality labels (see also A. keithi). However, it occurs in the Chinese provinces of Fujian, Guangdong, Guangxi, and Zheijiang (Lin 2002b).

\section{Anomala iridicollis OHAus, 1914}

Distribution: China (new country record), Vietnam.

Specimens examined: $30^{\star} o^{\star}, 7$ 우, Tam Dao, N. Vietnam, 28 30-IV-1991, M. Fujioka \& R. Muramoto leg. (MFPC); $1 \sigma^{\top}$, Tam Dao, N. Vietnam, 7-V-1992, 
T. Miyata leg. (MFPC); 1 ㅇ, Tam Dao, N. Vietnam, 3 28-V-1993, N. Katsura leg. (MFPC); 7 주 ๙ $^{*} 7$ 우 우, Sapa, N. Vietnam, 3 28-V-1993, N. Katsura leg. (MFPC); 9 o $^{\star} o^{*}, 9$ ㅇ ․, Tam Dao, N. Vietnam, 30-IV 6-V-1996, Y. Okushima leg. (HKPC); 1 ơ, Guangxi, Jingxiu, Luoxiang, 400 m, 1999.V.15., Xiao Lui lgt (GEI).

Remarks: Anomala iridicollis was hitherto known only from northern Vietnam. The above specimen from the GEI (examined by photograph) confirms it also occurs in the neighboring Chinese province of Guangxi.

\section{Anomala iwasei MıYAKE, 1994}

Distribution: China, Laos, Vietnam (new country record).

Specimens examined: Holotype: $\sigma^{*}$, Samneua Laos 20.VI.91 | Holotype: Anomala iwasei Y. MIYAKE, 1994 (RIEB). Additional material: $10^{\star}, 3$ 우, N. VIETNAM Lao Cai prov., Van Ban dist. Van Ban Nature Reserve (at light) ( 1000 m) 23.-26.V.2011, L. Bartolozzi, S. Bambi, F. Fabiano, E. Orbach leg. (MZUF); $1 \sigma^{*}$, LAOS north, 5-11.V.1997 $20 \mathrm{~km}$ NW Louang Namtha N2109.2.E $101^{\circ} 18.7$ alt. $900+-100$ m. M. Strba \& R. Hergovits leg. (VMPC).

Remarks: Anomala iwasei was originally described from Laos (Sam Neua) and occurs in Yunnan, China (Lin 1996a). Herein, we provide the first record of this species from Vietnam, where it interestingly occurs sympatrically with its very close relative A. sapa MiYAKe, 1994 in Lào Cai Province.

\section{Anomala jeanvoinei BENDERITTER, 1929}

Distribution: Vietnam.

Specimens examined: Holotype: $\sigma^{\star}$, Chapa, Tonkin (ex. Jeanvoine) Coll. Clermont | Anomala Jeanvoinei Bend [Benderitter's handwriting] E. Benderitter det. I Anomala jeanvoinei Cotype | MUSÉUM PARIS 1944 Coll. E. BENDERITTER (MNHN). Additional material: $3 \sigma^{\star} \sigma^{\star}$, VIETNAM, Lao Cai Prov., Hoang Lien NP, Tram Ton, $1915 \mathrm{~m}, 22.3493723^{\circ} \mathrm{N}, 103.7704565^{\circ} \mathrm{E}$, forest edge, at light, 8-11.IV.2010, leg. L. Papp, L. Peregovits \& Z. Soltész VN2010PL_4 (CZPC, HNHM).

Remarks: This species has not been reported since its description almost one hundred years ago. It was rediscovered in unidentified material within the HNHM, collected in 2010, not far from the type locality.

\section{Anomala katsurai MıYAKE, 1996}

Distribution: Vietnam.

Specimens examined: Holotype: ${ }^{\star}$, Pan-xi Pang near Sapa N. Vietnam 15.V.-1994 N. KATSURA | Holotype: Anomala katsurai Y. MIYAKE, 1994 (RIEB). Additional material: $1 \sigma^{\star}, 1+$, Sapa, N. Vietnam, 3 28-V-1993, N. Katsura leg. (MFPC); $6 o^{\top} o^{x}, 11$ 우, near Sapa, N. Vietnam, VI-1994, native collector leg. (MFPC); $1 \sigma^{\star}$, Cao Bang, alt. 1500-1900 m, N. Piaoac, Vietnam, 20 31-VII-1995, native collector leg. (MFPC); 3 o $^{\star}$, 4 우 오, Tam Dao, N. Vietnam, 17-30.VI.1999, A. Kallies leg. (CZPC).

Remarks: Anomala katsurai was known from the type locality only. The data above suggests a wider distribution in northern Vietnam.

\section{Anomala keithi Zorn, 2011}

Distribution: Vietnam.

Specimens examined: $30^{\star} \sigma^{\star}$, VIETNAM, Bac Kan Prov., Ba Be NP, Na Mam forest, 200 m, 22.417137ºN, $105.632505^{\circ} \mathrm{E}$, light trap, 17-19.IV.2010, leg. L. Papp, L. Peregovits \& Z. Soltész VN2010PL_17 (CZPC, HNHM); 1 ㅇ, N.-VIETNAM Bac Kan Prov., Ba Be NP. (entry), 16.-20.V.2014 22 25'07"N 105³8'09"E 180-220 m, leg. A. Skale (ASPC); 1 , N VIETNAM - Bac Kan province, Ba Be National Park ( 350m) (at light) 3-8. VI.2011 | L. Bartolozzi, S. Bambi, F. Fabiano, E. Orbach leg. (Num Magazzino 2909) (MZUF).

Remarks: The rediscovery of this species in the tropical lowland forests of $\mathrm{Ba} B \hat{e}$ in northern Vietnam (Bắc Kạn Province) leads to the conclusion that the type locality of this species (China, Daxue Shan in western Yunnan, $2600 \mathrm{~m}$ ) is incorrect. The holotype specimen was apparently obtained from an insect dealer and was incorrectly labeled. Therefore, this species should be deleted from the list of Chinese species of Anomala. The female specimens from Ba Bể appear to be very similar to the female type specimen of A. punctulicollis Fairmaire, 1893, collected in Hạ Lang (Cao Bằng Province). Whether these names are synonyms remains uncertain.

\section{Anomala laccata ZHANg \& LIN, 2008}

Distribution: China, Vietnam.

Specimens examined: $10^{\star}$, VIETNAM N 1990 Sa-Pa 11-19.VI., $1500 \mathrm{~m}$ Hoang Lien Son prov. Strnad Jan lgt. (CZPC); $10^{\star}$, N VIETNAM: Hoa Binh Prov. Pa Co Hang Kia Nature Reserve (900 m) 5-7/VI/2013 
at light | legit L. Bartolozzi, S. Bambi, F. Cianferoni, G. Mazza, E. Orbach (in Mag 2950) (MZUF); 5 o o , N.-VIETNAM Vinh Phu prov. Tam Dao, $1000 \mathrm{~m}$, 17.-30.VI.1999 A. Kallies leg. (CZPC); $30^{\star} 0^{\star}, 3$ 우 우, Vietnam N (Sa Pa) Lao Cai province, $250 \mathrm{~km}$ from Hanoi bearing $310^{\circ}, \mathrm{SaPa}$ vill. env. Hoang Lien Son Nat. Res. 18.06.-05.07.1998, h=1250 m, leg. A. Napolov (ANPC, CZPC).

Remarks: This species is currently known from the Vietnamese provinces of Hoàh Bình, Lào Cai, and Vĩnh Phúc. The "Tonkin Vinh Quang” record mentioned by ZHANG \& LiN (2008) could not be located.

\section{Anomala langbianensis ZoRN, 2011}

Distribution: Vietnam.

Specimens examined: $1 \sigma^{\star}$, Mt. Bralan, E. $45 \mathrm{~km}$, Bao loc, Lam Dong Prov., S. Vietnam, V-2005, native collector leg. (CZPC).

Remarks: Anomala langbianensis was known previously from two localities north of Dalat (Lâm Đông Province) (Prokofiev 2012, Zorn 2011). The location provided above extends the range of this species distinctly farther south.

\section{Anomala lignea ArRow, 1917}

Distribution: China, Laos, Thailand, Vietnam.

Specimens examined: $10^{*}, 2$ 우, N. VIETNAM Lao Cai prov., Van Ban dist. Van Ban Nat. Reserve (at light) ( 1000 m) 23.-26.V.2011, L. Bartolozzi, S. Bambi, F. Fabiano, E. Orbach leg. (MZUF); $1 \sigma^{\star}$, THAILAND. Chiang Mai Prov. Doi Inthanon N. P. Royal Project; 26 June 2002 coll. R. W. Sites (PLPC); 1 ơ $^{\star}$, Thailand: 29.5.5.6.1989 Doi Inthanon, Lichtfalle, Bang Khun Klang $1200 \mathrm{~m} \mathrm{98} 32^{\circ} \mathrm{E}, 18^{\circ} 32^{\prime} \mathrm{N}$ Chantaramongkol \& Malicky leg. (ZFMK); $10^{\star}$, NW Thailand, Chiang Dao, Ban San Pakia, 5.-10.V.2004; 1200 m, Sv. Bílý leg. (NMPC); $5 \sigma^{*} o^{*}, 1$, CHINA: S-YUNNAN (Xishuangbanna) 23 km NW Jinghong vic. Na Ban (NNNR) | N22 ${ }^{\circ} 09.49 /$

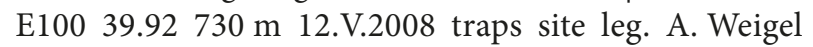
(CZPC, NME).

Remarks: Many species of the hirsutula-group (LIN, 1996a) seem to have rather small distribution ranges. In contrast, A. lignea is widely distributed from northern Myanmar (ARrow 1917) (type locality "Momeit" = Mongmit) in the west, to northern Vietnam in the east, including northern Thailand, Laos and southern Yunnan (China).

\section{Anomala luminosa BENDERITTER, 1929}

Distribution: Vietnam.

Specimens examined: $5 \sigma^{\star} \sigma^{*}$, Tam Dao, N. Vietnam, 30-IV 6-V-1996, Y. Okushima leg. (HKPC); 1 o , VIETNAM N, Ha Giang prov. 1500 m VII, 2011 M. Peijcha leg. (CZPC).

Remarks: Anomala luminosa was described from $\mathrm{Sa} \mathrm{Pa}$, northwestern Vietnam. Here we provided two additional records (Hà Giang Province, Vĩnh Phúc Province) in northern Vietnam.

\section{Anomala malaisei PAULIAN, 1959}

Distribution: Vietnam.

Specimens examined: $4 \sigma^{\star} o^{\star}, 2$ 우, S VIETNAM, $12.03 \mathrm{~N} 108.27 \mathrm{E}, 12 \mathrm{~km} \mathrm{~N}$ of Dalat - Lang Bian, 1580-1750 m, 17-21.iv.1995, Pacholátko \& Dembický leg. (CZPC, PPPC); $1 \sigma^{\star}, 1$ ㅇ, C VIETNAM: Kon Tum Province, surroundings Kon Plong, $1120 \mathrm{~m}$ $14^{\circ} 37,350 \mathrm{~N} 108^{\circ} 17,651 \mathrm{E}$ | leg. L. Bartolozzi, A. Bandinelli, S. Bambi, V. Sbordoni at light 4-7.V.2016 ( ${ }^{\circ} \mathrm{Mag}$. 3078) (MZUF).

Remarks: Previously known only from the type material, this species was re-discovered close to the type locality and has also been found in Kon Tum Province in central Vietnam.

\section{Anomala nigripes (NoNFRIED, 1892)}

Distribution: China, Myanmar (new country record), Thailand (new country record), Vietnam.

Specimens examined: $1 \sigma^{*}$, N. VIETNAM - Lao Cai prov., Van Ban dist. Van Ban Nat. Reserve (at light) ( 1000 m) 23.-26.V.2011, L. Bartolozzi, S. Bambi, F. Fabiano, E. Orbach leg. (MZUF); $70^{\star \top} o^{\star}, 2$ 우 오 N-VIETNAM Vinh Phu Pr. vic. Tam Dao NP, 02-5.V.2013 21 $27^{\prime} \mathrm{N}$ 105³8'E, 700-1000 m, leg. A. Weigel (CZPC, NME); $1 \sigma^{\star \top}$, 1 , N-VIETNAM: Vinh Phuc Prov. Tam Dao National Park, $950 \mathrm{~m}$ 5-12.VI.2010 L. Bartolozzi \& S. Bambi leg; ( $n^{\circ}$ Mag. 2894) (MZUF); $10^{*}$, N-VIETNAM Cao Bang Prov., vic. Vin Den, Nui Pia Oac Nature Reserve, 06.-10.V.2013, 22³3'53"N, 10552'53"E 900-1300 m leg. A. Weigel (NME); $10^{\star}$, THAI 1-8.V.1993 SOPPONG PAI $1800 \mathrm{~m}$ Pacholátko \& Dembický leg. (CZPC); $1 \mathrm{o}^{*}$, MYANMAR N (Burma) $21 \mathrm{~km}$ E Putao, H-550 m Nan Sa Bon vill. 1-5.5.98 leg. S. Murzin \& V. Siniaev (CZPC); $10^{*}$, CHINA, Guangdong prov. W of Qixing, 1-3.v.2011 Heishiding (stream, pools) (forested stream valley, at light) $23^{\circ} 27.9^{\prime} \mathrm{N}, 111^{\circ} 54.3^{\prime} \mathrm{E}, 190 \mathrm{~m} \mathrm{M}$. Fikáček \& J. Hájek leg. (NMPC); 1 ð, CHINA: S-YUNNAN 
(Xishuangbanna) $23 \mathrm{~km}$ NW Jinghong Na Ban village (NNNR) | N2209.49/E100 39.92 680 m 5.VI.2008 LF leg. A. Weigel station (CZPC, NME).

Remarks: Anomala nigripes was reported previously from the southeastern Chinese provinces of Guangxi, Guangdong and Fujian and the "Oriental Region" (Zorn 2006, ZORN \& BEZDĚK 2016). The distribution south of China includes northern Myanmar, Thailand and Vietnam, but no records from Laos are available. Additionally, this species was recorded in the Chinese province of Yunnan for the first time.

\section{Anomala nigroscutellata BENDERITTER, 1929}

Distribution: Laos (new country record), Thailand (new country record), Vietnam.

Specimens examined: 1 + , VIETNAM, Lao Cai Prov., Hoang Lien NP, Tram Ton, $1915 \mathrm{~m}, 22.3493723^{\circ} \mathrm{N}$, $103.7704565^{\circ} \mathrm{E}$, forest edge, at light, 8-11.IV.2010, leg. L. Papp, L. Peregovits \& Z. Soltész VN2010PL_4 (HNHM); 1 + , VIETNAM Lao Cai Prov. Sa Pa district, Sky Gate, 1800 m, at light, 29.-30.VIII.1998, leg. A. Kun (CZPC); 1 o , 1 , Coll. I.R.Sc.N.B. VIETNAM: Phia Den 08-VIII-2010, Light Trap I.G. 31.668 Leg. J. Constant \& P. Limbourg (CZPC); $10^{\star}, 1$ \% , NE-LAOS: Hua Phan prov.; Ban Saleui, Phou Pan (Mt.)- $20^{\circ} 12^{\prime} \mathrm{N}, 104^{\circ} 01^{\prime} \mathrm{E}$ 11.iv.-15.v.2012, 1300-1900 m leg. C. Holzschuh - ZFMK Ankauf 2012 (CZPC, ZFMK); $20^{\star} o^{\star}$, N-Thailand Nan Prov. Pua Doi Phu Kha km 351680 m 16.2.-1.3.1993 leg. D. Stüning (CZPC, ZFMK); 1 ㅇ, THAILAND, N; Chiang Mai, N; DOI Pha Hom Pok, $20^{\circ} 05^{\prime} \mathrm{N} 99^{\circ} 15^{\prime} \mathrm{E}, 23 .-29$. I.2004, leg. T. Ihle (CZPC).

Remarks: Though apparently rare, this species seems to be widely distributed in northern Southeast Asia. Anomala longiclypea LIN, 1999, described from Xishuangbanna, Yunnan, is most probably a synonym. The type material of the latter species could not be located.

\section{Anomala nubeculosa nubeculosa OHAus, 1905}

Distribution: China, Laos, Vietnam.

Specimens examined: $1 \sigma^{*}, 1 \%$, N-VIETNAM Vinh Phu Pr. vic. Tam Dao NP, 02-5.V.2013 212ㄱ'N 105³8'E, 700-1000 m, leg. A. Weigel (NME); 1 o $^{\star}$, Tam Dao, Vinh Phu Prov., N. Vietnam, 7-V-1992, T. Miyata leg. (MFPC); $1 \sigma^{\star}$, Tam Dao, N. Vietnam, V-1994, native collector leg. (MFPC); $11 \sigma^{\star} \sigma^{\star}$, Tam Dao, Vinh Phu Prov., N. Vietnam, 3-VI-1993, K. Matsumoto leg. (MFPC); 1 đ , 3 우 우, Tam Dao, Vinh Phu Prov., N. Vietnam, Y. Okushima leg. (HKPC), 2 o $^{\star} o^{\star}, 2$ 우 우, N-VIETNAM Cao Bang prov., vic. Vin Den, Nui Pia Oac NP, 06.-10.V.2013, 900-1300 m A. Skale leg. (ASPC); 1 조 3 우우, N-VIETNAM Cao
Bang Prov., vic. Vin Den, Nui Pia Oac Nature Reserve, 06.-10.V.2013, 22³3'53"N, 10552'53"E 900-1300 m leg. A. Skale (ASPC); $210^{\star} \sigma^{\star}, 36$ 우 우, NE-LAOS Hua Phan prov.: Ban Saleui, Phou Pan (Mt.) $\sim 20^{\circ} 12^{\prime} \mathrm{N} 104^{\circ} 01^{\prime} \mathrm{E}$; 1300-1900 m 01.-31.V.2011; leg. C. Holzschuh Ankauf ZFMK Bonn 2011 (CZPC, ZFMK); 1 ð , Damingshan, Guangxi Province, China 2013-VI Y.-Q. Lu leg (ZMPC).

Remarks: The nominate subspecies is currently known from northern Vietnam and Laos as well as from the Chinese provinces of Yunnan (ZoRN \& BEZDĚK, 2016) and Guangxi.

\section{Anomala planelytra PAULIAN, 1959}

Distribution: Vietnam.

Specimens examined: Holotype: $0^{\star}$, TYPE | Tuyen Quang Tonkin) Rau | MUSEUM PARIS Coll. L. Bedel 1922 | Ohaus determ. Anomala sp. | Anomala planelytra n. sp. R. Paulian det. | TYPE | Fig 184 (MNHN). Additional material: 2 우 우, N-VIETNAM Bac Kan Prov. Ba Bè NP., (entry), 16-20.V.2014, 22²5'07"N, 105³8'09"E, 180-220 m, leg. A. Skale (ASPC, CZPC).

Remarks: The two specimens from Ba Bể, (Bắc Kạn Province, Vietnam) represent the only recent record of this species, which had not been collected since its description.

\section{Anomala praeclara PAULIAN, 1959}

Distribution: China, Laos (new country record), Vietnam.

Specimens examined: 3 ㅇ ㅇ, N-Vietnam Lao Cai Prov., Hoanglien NP, Tram Ton, N22²1.197 E103²46.513 18002050 m. 13.-16.5.2015. leg. A. Skale (ASPC); 1 오, Tonkin, Chapa. VI.1918. R.V. de Salvasa. (NHML); $20^{\star} o^{\star}$, Vietnam N (Sa Pa) Lao Cai province, $250 \mathrm{~km}$ from Hanoi bearing $310^{\circ}$, SaPa vill. env. Hoang Lien Son Nat. Res. 30.05.-10.06.1998, h=1250 m Leg. A. Napolov (ANPC); $50^{\star} 0^{\star}, 2$ 우 우, LAOS-NE; HUA PHAN prov. BAN SALUEI; Phu Phan Mt.; $20^{\circ} 13^{\prime} \mathrm{N} 103^{\circ} 59^{\prime} \mathrm{E}$; 1300-2000 m; 06.-18.iv.2004 J. Bezděk leg. (CZPC); $50^{\star} o^{\star}, 12$ 우 우, LAOS-NE; HUA PHAN prov. BAN SALUEI; Phu Phan Mt.; $20^{\circ} 15^{\prime} \mathrm{N}$ 10402'E; 1500-2000 m; 26.iv.-11.v.2001 J. Bezděk \& D. Hauck leg. (CZPC); 1 + , China, Yunnan Prov. E101'53'33" N2518'37" Lufeng (county) Gaofeng (village), $2080 \mathrm{~m}$ 11.-14. June 2013, lux leg. A. Kallies \& M. Owada (CZPC).

Remarks: This species, previously known only from northwestern Vietnam and Yunnan (China), is here reported from Laos for the first time. 


\section{Anomala praecoxalis OHAUS, 1914}

Distribution: China, Laos (new country record), Thailand (new country record), Vietnam.

Specimens examined: $20^{\star} o^{\star}, 5$ 우, N. VIETNAM Lao Cai prov. Hoang Lien NP, surr. Sa Pa pass, at light $(\sim 1900 \mathrm{~m})$ 27.V.-2.VI.2011, L. Bartolozzi, S. Bambi, F. Fabiano, E. Orbach leg. (CZPC, MZUF); $30^{x} \sigma^{x}, 1$ 우, Vietnam-N, Lao Cai Prov., Hoang Lien Son Nat. Res., Sa Pa vill. env., 27.5.-2.6.1998, Lg.A. Napolov $\mid 22^{\circ} 20^{\prime} \mathrm{N} 103^{\circ}$ $50^{\prime} \mathrm{E} h=1250 \mathrm{~m}$ (ANPC); $10^{*}, \mathrm{~N}$ Viet Nam (Tonkin) pr. Vinh Phu 1990 TAM DAO 6.- 9.v. Vit Kuban leg. (CZPC); $2 \sigma^{\star} \sigma^{\star}$, N. VIETNAM: Ha Gang prov. Hoang So Phi distr. Thong Nguyen env., 378 m, 22³4'630"N 10444'700"E IV 2013 leg. Binh Nguyen (ARPC); $10^{*}$, N-VIETNAM Cao Bang Prov., vic. Tinh Tuc, Nui Pia Oac Nature Reserve, 19.-15.V.2013, 22³7'55"N, 10552'98"E 850-1300 m leg. A. Skale (ASPC); $10^{\star}$, N. THAILAND Phetchalbun Prov. Khao Kau Distr. Ban Nang Mae Na 1300 m; 27.-28.2.2005 (VMPC); $120^{\top} 0^{\star}, 26$ 우, LAOS-NE; HUA PHAN prov. BAN SALUEI; Phu Phan Mt.; $20^{\circ} 15^{\prime} \mathrm{N} 104^{\circ} 02^{\prime} \mathrm{E}$; 1500-2000 m; 26.iv.-11.v.2001 J. Bezděk \& D. Hauck leg. (CZPC); 1 \% , CHINA-YUNNAN 28.5.-9.6.1994 DALI lgt. Kučera (CZPC); $4 \sigma^{*} \sigma^{*}, 2$ ㅇ 9 , China, Yunnan Prov. E101 $533^{\prime} 33^{\prime \prime}$ N25 ${ }^{\circ} 18^{\prime} 37^{\prime \prime}$ Lufeng (county) Gaofeng (village), $2200 \mathrm{~m}$ 09.-13. June 2013, lux leg. A. Kallies \& M. Owada (CZPC); 1 ㅇ, CHINA-YUNNAN 10.-1.-6.1994 LITIANG lgt. Kučera (CZPC); 1 o , Chi na. Prov. Yunnan, Vallis flumin, Soling-ho. [=Longchuan Jiang] (CZPC); 1 , CHINA: S-YUNNAN (Xishuangbanna) $27 \mathrm{~km} \mathrm{NW}$ Jinghong vic. Beng Gang Ha Ni | N22 ${ }^{\circ} 08.74$; E100 35,50 1800-2000 m 29.V.2008 leg. A. Weigel KL/HF (AWPC).

Remarks: This species, previously recorded from southern China (provinces of Yunnan and Guizhou) and northern Vietnam (PAULIAN 1959, ZORN \& BEZDĚK 2016), is here recorded from Laos and Thailand for the first time.

\section{Anomala raui OHAUs, 1914}

Distribution: China, Vietnam.

Specimens examined: 1 \%, Ht. TONKIN Lao-Kai R.V.d.Salvaza | o | Cotype | Anomala Raui Ohs. | Anomala generosa Bend. M.d.Type vergl. Mz. 23.8.30. (ZMB); 1 ơ, Tonkin. Ban Nam Coun. [=Ban Nam Muong, Lai Châu Province?] Aug. 1917. R.V.de Salvasa. (BMNH); 1 으, Tonkin Langson 16.3.1916 R.V.de Salvasa. 1916-208. (BMNH); $10^{\star *}, 4$ ㅇ ㅇ , MUSEUM PARIS Frontière ChineRégion de Lao Kay et Ho Kheou [= China, Yunnan Prov. Hekou Yao Autonomous county, Hekou-Lào Cai border bridge $=\mathrm{N} 22^{\circ} 30.4^{\prime} \mathrm{E} 103^{\circ} 57.8^{\prime}, 80 \mathrm{~m}$, locality data taken from Murányi \& Li (2015)] Ch, Dupont 1900 (CZPC,

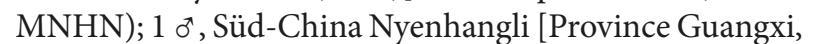
see Nonfried, 1892] Coll. Nonfried (ZMB).
Remarks: This species is known only from historical material collected in northern Vietnam, Yunnan and Guangxi.

\section{Anomala rufiventris Kollar \& RedtenBACHeR, 1844}

Distribution: Bhutan, China, India, Nepal, Vietnam.

Specimens examined: $20^{\star} o^{\star}$, N VIET NAM (Tonkin) pr. Hoang Lien Son SA PA 11.-15.V.1990 P. Pacholátko leg. (PPPC); $2 \sigma^{\star} \sigma^{*}$, VIETNAM N, 25.5.-10.6. SAPA 199122 20'N 103 50'E E. Jendel leg. (CZPC); 1 ơ $^{\star}$, Tam Dao, N. Vietnam, VI-VII-1997, native collector (CZPC); $1 \sigma^{*}$, N-VIETNAM, Prov. Lao Cai, Bac Ha, 950 m, 28.-30.V.1999, Ahrens, Jäger, Fabrici leg. (CZPC); $10^{*}$, N-Vietnam Lao Cai Prov., Hoanglien NP, Tram Ton, $\mathrm{N} 22^{\circ} 21.197$ E1034․ ${ }^{\circ} 413$ 1800-2050 m. 13.-16.5.2015. leg. A. Skale (ASPC).

Remarks: The population in northeastern Vietnam represents the eastern-most record of A.rufiventris, which is widely distributed in the Himalayan Arc (ZORN \& BEZDĔK 2016).

\section{Anomala sapa MıYAKe, 1994}

Distribution: China, Vietnam.

Specimens examined: Holotype: $0^{\star}$, Sapa, Tonkin 1.VI.1993 M. ITO leg. | Holotype: Anomala iwasei sapa Y. MIYAKE, 1994 (RIEB). Additional material: $3 \sigma^{\top} \sigma^{*}$, Sapa, N. Vietnam, 3 28-V-1993, N. Katsura leg. (MFPC); 2 ㅇ 우, Cao Bang, N. Vietnam, 8 10-VI-1993, native collector leg. (MFPC); 1 우, Cao Bang, N. Vietnam, 5-VI-1995, Itoh leg. (MFPC); 1 o , 1 , Mt. Pia Oac, Cao Bang Pref., N. Vietnam, 22 29-V-1998, H. Karube leg. (MFPC); $1 \sigma^{\star}$, N. VIETNAM - Lao Cai prov., Van Ban dist. Van Ban Nat. Reserve (at light) ( 1000 m) 23.-26.V.2011, L. Bartolozzi, S. Bambi, F. Fabiano, E. Orbach leg. (MZUF); $1 \sigma^{\star}, 1$ ㅇ, N-VIETNAM, Lao Cao Prov. Hoang Lian NP, 1250 m, Cat Cat 15.V.2015, $\mathrm{N} 22^{\circ} 19.27^{\prime} \mathrm{E} 103^{\circ} 49.60 \mathrm{HF} / \mathrm{KL}$ leg. A. Weigel (NME); $2 o^{\star} o^{\star}, 2$ 우, ‥ N.-VIETNAM Vinh Phu prov. Tam Dao, $1000 \mathrm{~m}$ 17.-30.VI.1999 A. Kallies leg. (CZPC); $1 \sigma^{\star}$, N-VIETNAM Thai Nguyen Prov., Ngoc Thanh, Me Linh (IEBR station), 12.V.2012, 21 ${ }^{\circ} 23^{\prime} 3^{\prime \prime} \mathrm{N}, 105^{\circ} 42^{\prime} 44^{\prime \prime} \mathrm{E}$, leg. A. Skale (KL/KF) (ASPC); $10^{\star}$, N-VIETNAM Cao Bang Prov., vic. Tinh Tuc, Nui Pia Oac Nature Reserve, 19.-15.V.2013, 22³7'55"N, 10552'98"E 850-1300 m leg. A. Skale (ASPC).

Remarks: Within Vietnam, A. sapa was recorded only from the type locality: $\mathrm{Sa} \mathrm{Pa}$ (Lào Cai Province). The new records provided here expand the known distribution range considerably. 


\section{Anomala schereri FREY, 1965}

Distribution: China, India (Assam), Laos (new country record), Thailand (new country record), Vietnam (new country record).

Specimens examined: Holotype: $0^{\star}$, ASSAM, Khasi Hills, Shillong 1500 m, V.1961 leg. G. Scherer | Type | Typus Anomala schereri n. sp. det. G. Frey, 1963 (NMBS). Paratypes: $20^{\star} o^{\star}, 1$ ㅇ, ASSAM, Khasi - Hills, Shillong 1500 m, V. 1961 leg. G. Scherer | P. Type | Typus Anomala schereri n. sp. det. G. Frey, 1963 (NMBS). Additional material: $1 \sigma^{*}, 2$ ㅇ $\circ \mathrm{C}$, N.-VIETNAM Bac Kan Prov., Ba Be NP. (entry), 16.-20.V.2014 22²5'07"N $105^{\circ} 38^{\prime} 09^{\prime \prime E ~ 180-220 ~ m, ~ l e g . ~ A . ~ S k a l e ~(A S P C) ; ~} 3$ o $^{\top} \mathrm{o}^{\top}$, NE-LAOS: Hua Phan prov.: Ban Saleui, Phou Pan (Mt.) $\sim 20^{\circ} 12^{\prime} \mathrm{N}$ 104 ${ }^{\circ} 01^{\prime} \mathrm{E}$ 11.iv.-15.v.2012, 1300-1900 m leg. C. Holzschuh - ZFMK Ankauf 2012 (CZPC, ZFMK); $10^{7}$, N. LAOS: Phong Sali M Phong Sali 15-17-V-1996 coll. C. L. Li (CZPC); $10^{\star}$, LAOS $21^{\circ} 09^{\prime} \mathrm{N} 101^{\circ} 19^{\prime} \mathrm{E}$ Louangnamtha pr. Namtha-MuangSing 5-31.v.1997. 900 Vit Kuban leg. $1200 \mathrm{~m}$ (PPPC); $10^{\star}$, THAILAND: Nan Province Amphur Bo Kluea; Tumbon Phufa Doi Phuka Park Ranger Station $619^{\circ} 01^{\prime} \mathrm{N} 101^{\circ} 11^{\prime} \mathrm{E} ; 538 \mathrm{~m}$; L-473 pan UV light trap; 21 April 2003 Vitheepradit, Prommi, Setaphan (PLPC); 1 우 THAILAND: Phrae Province Wieng Ko Sai N.P.; 350 m 17²58'N 99³5'E; 29 III 2003 pan UV light trap; L-425 Sites, Vitheepradit, Prommi (PLPC); 1 i , THAILAND: Phitsanulok Prov. Phu Hin Rongkla NP; guest house pan UV trap; $17^{\circ} 00^{\prime} \mathrm{N} 100^{\circ} 59^{\prime} \mathrm{E}$ 1144 m; 6 May 2003; L-508 Vitheepradit, Prommi, Ferro (PLPC); $10^{\star}$, W. THAILAND Kanchanaburi Prov. Si Sawat Distr. Ban Dong Lek 735 m 2.-3.3.2005 K. Cerny lgt. (VMPC); 1 क , Chiang Mai distr. 1996 Dol Pul vill. 1849' 9854' J. Horak lgt.; 1600 m (CZPC); $1 \sigma^{\top}$, SOPPONG PAI $1800 \mathrm{~m}$ Pacholátko \& Dembický leg. (CZPC); $1 \varnothing^{\star}$, THAILAND: Loei province Na Haew N.P. lights at guest house; 25. April 2003; L-485 Vitheepradit, Prommi, Setaphan (CZPC); $10^{\circ}$, THAILAND: Chiang Mai Prov. Doi Inthanon N.P.; Nam Tok Sob Ab; $18^{\circ} 31^{\prime} \mathrm{N} 98^{\circ} 36^{\prime} \mathrm{E} 543$ m; 17 May 2004; L-690 colls: Vitheepradit \& Prommi (CZPC); $10^{\star}$, CHINA: S-YUNNAN (Xishuangbanna) $23 \mathrm{~km} \mathrm{NW}$ Jinghong $\mathrm{Na}$ Ban village (NNNR) | N22 09.49/E100 39.92680 m 5.VI.2008 LF leg. A. Weigel station (CZPC); $10^{*}, 3$ 우 우, CHINA, Hainan Isl. 9-11.v.2011 Jianfengling Mts., Tiachi Lake env. Bishu Villa (at light) $18^{\circ} 44^{\prime} 40^{\prime N}$ 10850'41"E 950 m M. Fikáček, V. Kubeček \& L. Li leg. (NMPC).

Remarks: Anomala schereri was described from Assam, India, which appears to represent the western distribution limit of this species. The eastern-most record is Hainan, China. This species occurs in Yunnan and the northern parts of Thailand, Laos and Vietnam. It should occur in Myanmar as well, but no records are known to the authors.

\section{Anomala spiloptera BURMEISTER, 1855}

Distribution: China, Vietnam (new country record), Bhutan [?], India (Sikkim) [?].

Specimens examined: $1 \sigma^{\star}, 1$ ㅇ, Tonkin Montes Mauson April, Mai 2-3000' H. Fruhstorfer (CZPC, ZMB); $1 \sigma^{\star}$, Chusan Is., China. J.J.W. (NHML); $10^{\star}$, Kiukiang H. Schulz (HNHM); 1 o $^{\star}, 2$ 우 우, CHINA, Hainan Isl., 4-6.v.2011 Limushan Mts. frst administr. centre (at light) $19^{\circ} 10^{\prime} 30^{\prime \prime N}, 109^{\circ} 44^{\prime} 33 " E, 630$ m M. Fikáček, V. Kubeček \& L. Li leg. (NMPC); 1 o $^{*}$ Himalaya Sikkim | 85 | A. flavomaculata Arr. [sic!] Ohs. [Ohaus's handwriting] (ZMB).

Remarks: The records from the Himalaya, as presented by ZoRn (2006) and ZoRn \& BEZDĚK (2016) are doubtful. They were based on a single historical specimen labeled "Sikkim Himalaya" (ZMB) and a record from Bhutan published by FrEY (1975). The associated material could not be found at the NMBS. Distribution limits within China are still uncertain. It is possible that this species occurs only in southeastern China and northern Vietnam.

\section{Anomala spilopteroides OHAUs, 1914}

Distribution: Vietnam.

Specimens examined: $1 \sigma^{x}$, Cao Bang, N. Vietnam, 5-VI1996, Itoh leg. (MFPC); 1 o $^{\star}$, Mt. Pia Oac, Cao Bang Pref., N. Vietnam, 22 29-V-1998, H. Karube leg. (MFPC).

Remarks: Known previously only from the type locality, Mt. Mẫu Sơn, this species is here reported from two additional localities in northern Vietnam.

\section{Anomala trivirgata FAIRMAIRE, 1888}

Distribution: Bhutan, China, Nepal, Vietnam.

Specimens examined: $10^{\star}$, N.-Vietnam Vinh Phu Prov., Tam Dao, ca. 1000 m 17.-30.VI.1999, A. Kallies leg. (CZPC); $10^{\star}$, N. VIETNAM, Lao Cai Prov., Sapa Distr. Ta Phin 2136 m, 22²2'49" N, 10348'49" E V 2013 leg. Hua Binh Nguyen (ARPC); 3 우, N. VIETNAM, Lao Cai Prov., Mt. Fan Si Pan, $22^{\circ} 22^{\prime}$ N, 10350' E, 22 V 2012, leg. Hua Binh Nguyen (ARPC); 4 우, N. VIETNAM, Vinh Phuc Prov. Tam Dao NP, 965 m, 21ํ2'23" N, $105^{\circ} 38^{\prime} 58^{\prime \prime}$ E, 23 VI 2011, leg. Hua Binh Nguyen (ARPC); $2 o^{\star} o^{\star}, 1$ ㅇ, VIETNAM, Lao Cai Prov., Hoang Lien NP, Tram Ton, $1915 \mathrm{~m}, 22.3493723^{\circ} \mathrm{N}, 103.7704565^{\circ} \mathrm{E}$, forest edge, at light, 8-11.IV.2010, leg. L. Papp, L. Peregovits \& Z. Soltész VN2010PL_4 (CZPC, HNHM); $10^{\star}$, Annam | Ohaus determ. Anomala trivirgata Fairm. (NMPC). 
Remarks: All specimens from northern Vietnam (but not the specimen from "Annam") are slightly less elongate and more shining than are those from other localities, but aedeagal structure remains consistent.

\section{Anomala variivestis ARRow, 1917}

Distribution: China (new country record), India, Laos, Myanmar, Thailand (new country record), Vietnam.

Specimens examined: $8 \sigma^{\star} \sigma^{*}, 9+\%$, N. VIETNAM - Lao Cai prov., Van Ban dist. Van Ban Nat. Reserve (at light) $(\sim 1000 \mathrm{~m}) \quad 23 .-26$. V.2011, L. Bartolozzi, S. Bambi, F. Fabiano, E. Orbach leg. (CZPC, MZUF); 1 ơ $^{\star}$ N-VIETNAM, Prov. Lao Cai, Bac Ha, 950 m, 28.-30.V.1999, Ahrens, Jäger, Fabrici leg. (CZPC); $10^{\star}$, N-VIETNAM, Prov. Lao Cai, Bac Ha, 950 m NN $\mathrm{N} 22^{\circ} 32^{\prime} 05, \mathrm{E} 104^{\circ} 17^{\prime} 32 \mathrm{E}, 28 .-30 . \mathrm{V} .1999$, Ahrens, Jäger, Fabrici leg. (CZPC); $10^{\star}, 2$ 우, N-VIETNAM Cao Bang Prov., vic. Vin Den, Nui Pia Oac Nature Reserve, 06.-10.V.2013, 2233'53"N, 10552'53"E 900-1300 m leg. A. Skale (ASPC); $10^{\star}$, LAOS 4.v.1997. Louangnamtha pr. $21^{\circ} 09^{\prime} \mathrm{N} 101^{\circ} 19^{\circ} \mathrm{E}$ LOUANG NAMTHA, Vít Kubán leg. $600 \mathrm{~m}$ (PPPC); 5 ๙ o $^{\star}, 3$ ㅇ ㅇ , NE-LAOS Hua Phan prov.: Ban Saleui, Phou Pan (Mt.) $20^{\circ} 12^{\prime} \mathrm{N} 104^{\circ} 01^{\prime} \mathrm{E} ; 1300-$ 1900 m 01.-31.V.2011; leg. C Holzschuh Ankauf ZFMK

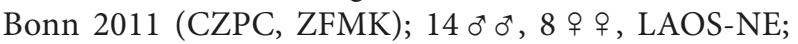
HUA PHAN prov. BAN SALUEI; Phu Phan Mt.; $20^{\circ} 15^{\prime} \mathrm{N}$ 104ํํ'ㄹ; 1500-2000 m; 26.iv.-11.v.2001 J. Bezděk \& D. Hauck leg. (CZPC); $2 \sigma^{\star} \sigma^{\star}, 3$ 우, N. LAOS: Phong Sali M Phong Sali 15-17-V-1996 coll. C. L. Li (CZPC); $30^{\star} o^{\star}, 1$ ㅇ, LAOS-N; Xieng Khuang prov. Nong Haet $19^{\circ} 30^{\prime} \mathrm{N} 104^{\circ} 03^{\prime} \mathrm{E} ; 29 .-31 . v .2001$ D. Hauck leg. (CZPC); $2 o^{*} o^{*}, 1$ \% , THAI-N. 1.-19.v.1998 Chiang Mai prov., Ban Sanpakia, $1400 \mathrm{~m}$ Ivo Martinů leg. (CZPC); $1 \delta^{\star}$, THAILAND-N Mae Salong env., $50 \mathrm{~km} \mathrm{NW} \mathrm{Chiang}$ Rai 30.iv.-2.v.2003 O. Safránek leg. (CZPC); $150^{\star} \sigma^{\star}$, 4 우 우, NW THAILAND, 9.-16.V. Mae Hong Son, 1991 Ban Huai Po, $1600 \mathrm{~m}$ P. Pachlátko leg. (CZPC); $10^{\star}$,

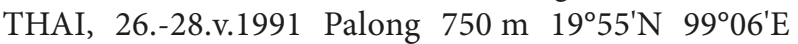
Vit Kubán leg. | Thailand '91 Thanon Thong Chai D. Král \& V. Kubán (CZPC); $20^{\star} o^{\star}, 3$ 우 우, THAI-N, Nan Prov.19 $13^{\prime} \mathrm{N} 101^{\circ} 7^{\prime} \mathrm{E}$ Doi Phukha N.P. Headq. 22-26. iv.1999 $1500 \mathrm{~m}$ D. Hauck leg. (CZPC); $1 \sigma^{*}$, Coll. I.R.Sc. N.B. Thailande (Loei) Na Haeo (bio. station) 05-12.V.2001 Light trap Leg. Constant \& Grootaert (RBINS); 3 우, MYANMAR N (Burma) $21 \mathrm{~km} \mathrm{E}$ Putao, H-550 m Nan Sa Bon vill. 1-5.5.98 leg. S. Murzin \& V. Siniaev (CZPC); 1 ㅇ, CHINA: S-YUNNAN (Xishuangbanna) $37 \mathrm{~km}$ NW Jinghong Guo Men Shan NNNR | N22 ${ }^{\circ}$ 17.91; E100 38.851080 m 26.V.2008 leg. A. Weigel KL/HF (CZPC); 1 ㅇ, CHINA: S-YUNNAN (Xishuangbanna) $27 \mathrm{~km} \mathrm{NW}$ Jinghong vic. Beng Gang Ha Ni | N2208.74; E100 35,50 1800-2000 m 29.V.2008 leg. A. Weigel KL/HF (AWPC).
Remarks: Originally described from Assam and Myanmar (Pyin U Lwin), Anomala variivestis appears to be a widely distributed species in mainland Southeast Asia (see also Prokofiev 2015a). Here, we report it from China and Thailand for the first time.

\section{Anomala vietnamica MIYAKE, 1996}

Distribution: Vietnam.

Specimens examined: Holotype: $\iota^{\star}$, Sapa $=$ Chapa N. Vietnam 20-V-1995 N. KATSURA | Holotype: Anomala vietnamica Y. MIYAKE, 1996 (RIEB). Additional material: $6 o^{\star} o^{\star}, 6$ 우 웅 Cao Bang, alt. 1500-1900 m, N. Piaoac, Vietnam, 20 31-VII-1995, native collector leg. (MFPC); $2 \sigma^{\star} \sigma^{\star}$, Phia Den, Vietnam, 08.VIII.2010, J. Constant \& P. Limbourg leg. (CZPC, RBINS).

Remarks: Described from Sa Pa in northwestern Vietnam, this species also occurs in Cao Bằng province, suggesting a wider distribution in northern Vietnam.

\section{Anomala viridicostata NonfRIED, 1892}

Distribution: China, Vietnam (new country record).

Specimens examined: Syntype: $1 \sigma^{\top}$, Coll. Nonfried, China | Type | Anomala viridicostata China Type A.f. Nonfried (ZMB). Additional material: $10^{*}$, Tonkin Montes Mauson April, Mai 2-3000' H. Fruhstorfer (ZMB); 1 ㅇ, China Prov. Fo-Kien G. Siemssen | Anomala viridicostata Nonfr. Cotype + [Ohaus's handwriting, no syntype!] (ZMB); 1 , FOKIEN Fu-chou | Anomala viridicostata Nonfr. Cotype + [Ohaus's handwriting, no syntype!] (ZMB); 1 \%, CHINA - GANSU BIKOU $32^{\circ} 32^{\prime} \mathrm{N} 104^{\circ} 38^{\prime} \mathrm{E}$ 3.7.-7.7.97 lgt. E. Kučera (CZPC); 1 , China West. Sichuan Moximian. Luding Co 13.-18.7.94 Benes (CZPC); 1 \% , CHINA, Guangdong prov. W of Qixing, 1-3.v.2011 Heishiding (stream, pools) (forested stream valley, at light) $23^{\circ} 27.9^{\prime} \mathrm{N}, 111^{\circ} 54.3^{\prime} \mathrm{E}$, 190 m M. Fikáček \& J. Hájek leg. (NMPC); $170^{\star} o^{\star}, 1$ 우, CHINA, Guangdong prov. Nanling National Nature Reserve Dadongshan, 18-21.iv.2013 (border of mixed forest, at light) $24^{\circ} 56.0^{\prime} \mathrm{N}, 112^{\circ} 42.9^{\prime} \mathrm{E}, 690 \mathrm{~m}$ J. Hájek \& J. Růžička leg. (NMPC).

Remarks: This species has a wide range within China (ZORN \& BEZDĚK 2016). Its presence in Vietnam is now confirmed by a historical specimen collected by H. Fruhstorfer at Mt. Mẫu Sơn near the beginning of the last century. 


\section{Anomala viridisericea OHAUs, 1905}

Distribution: China, Laos, Vietnam.

Specimens examined: $10^{x}, 1$ ㅇ, N-VIETNAM Cao Bang Prov., vic. Vin Den, Nui Pia Oac Nature Reserve, 06.-10.V.2013, 22³3'53"N, 10552'53"E 900-1300 m leg. A. Skale (ASPC); 1 ๙ $^{\star}, 1$ ㅇ, N-Vietnam Cao Bang Prov. vic. Tinh Tuc, Son Dong, Nui Pia Oac Nature Reserve, 9.-15.V.2014, 22³7'55"N, 10552'98"E 850-1300 m leg. A. Skale (ASPC); 1 ㅇ, 2 우 은 N-VIETNAM Vinh Phuc Prov., vic. Tam Dao Town, Tam Dao NP, 02.-5.V.2013, $21^{\circ} 27^{\prime} \mathrm{N}, 105^{\circ} 38^{\prime} \mathrm{E}, 700-1000 \mathrm{~m}$, leg. A. Skale (ASPC); 1 ㅇ, N-VIETNAM Thai Nguyen Prov., Ngoc Thanh, Me

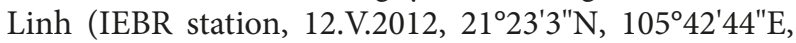
leg. A. Skale (KL/KF) (ASPC); $20^{\star} 0^{\star}, 4$ 우, N.-Vietnam, Bac Giang Prov. Tay Yen Tu Nat. Res. Thanh So'n

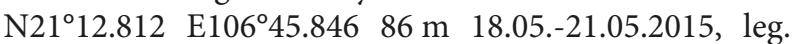
A. Skale (ASPC); $10^{\star}$, N. VIETNAM - Lao Cai prov., Van Ban dist. Van Ban Nature Reserve (at light) ( 1000 m) 23.-26.V.2011, L. Bartolozzi, S. Bambi, F. Fabiano,

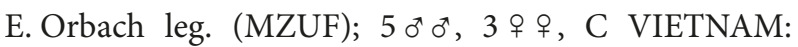
Kon Tum Province, ca. $30 \mathrm{~km}$ from Kon Plong, $1250 \mathrm{~m}$ $14^{\circ} 40,320 \mathrm{~N} 108^{\circ} 15,829 \mathrm{E} \mid$ leg. L. Bartolozzi, A. Bandinelli, S. Bambi, V. Sbordoni at light 4-7.V.2016 (nMag. 3078) (CZPC, MZUF); $40^{\star} o^{\star}, 1$ ㅇ, C VIETNAM: Thua Thien-Hue Prov., A Luoi District, Sao La Nature Reserve $(600-650 \mathrm{~m}) 16.077^{\circ} \mathrm{N} 107.488^{\circ} \mathrm{E} \mid 20-27 . V .2017$ L. Bartolozzi, E. Orbach, V. Sbordoni, S. Bambi \& A. Bandinelli leg. at light (numero Mag. 3089); $20^{\star} 0^{\star}$, NE-LAOS Hua Phan prov.: Ban Saleui, Phou Pan (Mt.) $\sim 20^{\circ} 12^{\prime} \mathrm{N} \quad 104^{\circ} 01^{\prime} \mathrm{E} ; 1300-1900 \mathrm{~m}$ 01.-31.V.2011; leg. C. Holzschuh Ankauf ZFMK Bonn 2011 (CZPC, ZFMK); 1 ․ LAOS, ATTAPEU prov. Annam Highlands Mts. Dong Amphan NBCA, ca. 1160 m NONG FA [crater lake], env. $15^{\circ} 05.9^{\prime} \mathrm{N}, 107^{\circ} 25.6^{\prime} \mathrm{E}$ Jiří Hájek leg. 30.iv.6.v.2010 (NMPC); $10^{\star}$, SE China, Guangdong Prov. Shaoguan Distr., Nanling Mts Nature Res. Guest house

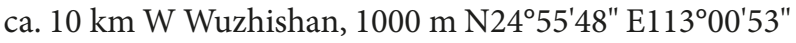
2.-6.VII.2012 lux leg. A. Kallies \& Y. Arita (CZPC); $10^{\star}, 1$ ㅇ, CHINA WuyShan prov. Jiangxi-Fujian border

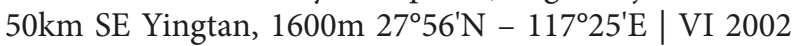
leg. V. Siniaev \& local collectors (CZPC); $10^{\star}$, CHINA, Hainan Isl., 7-8.v.2011 Bawangling Mts., BAOTIE env. (at light) $19^{\circ} 05.3 \mathrm{~N} 108^{\circ} 07.4^{\prime} \mathrm{E} ; 415-800 \mathrm{~m} \mathrm{M}$. Fikáček, V. Kubeček \& L. Li leg. (NMPC); 1 ㅇ, CHINA, Hainan Isl. 9-11.v.2011 Jianfengling Mts., Tiachi Lake env. Bishu Villa (at light) 1844'40"N 10850'41"E 950 m M. Fikáček, V. Kubeček \& L. Li leg. (NMPC).

Remarks: The known distribution of this species includes southeastern China, northern and Central Vietnam, and Laos (Frey 1970, OHAus 1905, Zorn \& BEZDĚK 2016). There are very slight differences in the shape of the aedeagus across the range of the species, but the taxonomic significance of this is not clear.

\section{Anomala vitalisi OHAUs, 1914}

Distribution: China, Laos (new country record), Vietnam.

Specimens examined: $5 \sigma^{\star} o^{\star}$, Sapa, N. Vietnam, 3 28-V-1993, N. Katsura leg. (MFPC); $20^{\star} o^{\star}, 3$ 우 우, N. VIETNAM - Lao Cai prov. Hoang Lien NP, surr. Sa Pa pass, at light $(\sim 1900 \mathrm{~m})$ 27.V.-2.VI.2011, L. Bartolozzi, S. Bambi, F. Fabiano, E. Orbach leg. (MZUF); $60^{\text {đ }} 0^{\text {, }}$, 4 우오, N-Vietnam Lao Cai Prov., Hoanglien NP,

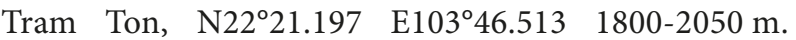
13.-16.5.2015. leg. A. Skale (ASPC); $5 \sigma^{\star} o^{\star}$, N-VIETNAM: Vinh Phuc Prov. Tam Dao National Park, $950 \mathrm{~m}$ 5-12.VI.2010 L. Bartolozzi \& S. Bambi leg; ( ${ }^{\circ} \mathrm{Mag}$. 2894) (MZUF); 5 o $^{*}, 7$ 우 + NE-LAOS: Hua Phan prov.: Ban Saleui, Phou Pan (Mt.) $\sim 20^{\circ} 12^{\prime} \mathrm{N} 104^{\circ} 01^{\prime} \mathrm{E}$ 11.iv.-15.v.2012, 1300-1900 m leg. C. Holzschuh ZFMK Ankauf 2012 (CZPC, ZFMK); 5 우 우, NE-LAOS Hua Phan prov.: Ban Saleui, Phou Pan (Mt.) $\sim 20^{\circ} 12^{\prime} \mathrm{N}$ 10401'E; 1300-1900 m 01.-31.V.2011; leg. C. Holzschuh Ankauf ZFMK Bonn 2011 (CZPC, ZFMK); 1 ㅇ, China Canton Lehmann S. | 87879| 우 (ZMB).

Remarks: Anomala vitalisi was previously known from southeastern China and northern Vietnam (OHAus 1914, Paulian 1959, Zorn \& BezděK 2016). The recent records from Laos extend the known distribution to the southwest.

\section{Anomala wapiensis FreY, 1971}

Distribution: Laos, Vietnam (new country record).

Specimens examined: Holotype: $\sigma^{\star}$, Südl. Laos Wapi, 1967 | TYPE | Type Anomala wapiensis n. sp. det. G. Frey, 1970 (NMBS); Paratype: 1 우 ㅇ | Südl. Laos Wapi, 1967 | PARATYPE | Anomala wapiensis n. sp. det. G. Frey, 1970 (NMBS). Additional material: $60^{\star \top} o^{7}$, 4 우 오, S VIETNAM, $14.10 \mathrm{~N} 108.30 \mathrm{E} 40 \mathrm{~km} \mathrm{NW}$ of An Khe Buon Luoi, 620-750 m 28.3.-12.4.1995 Pacholátko \& Dembický leg. (CZPC, PPPC); 1 ○, 2 우 운, LAOS, ATTAPEU prov. Annam Highlands Mts. Dong Amphan NBCA, ca. 1160 m NONG FA [crater lake], env. $15^{\circ} 05.9^{\prime} \mathrm{N}, 107^{\circ} 25.6^{\prime} \mathrm{E}$ Jiří Hájek leg. 30.iv.-6.v.2010 (NMPC).

Remarks: This species was described from Muang Vapi, Salavan Province, Laos and has recently been collected in Vietnam, Gia Lai Province and Laos, Attapeu Province. These specimens represent the first collected since its description. 


\section{Anomala yunnana FAIRMAIRE, 1886}

Distribution: China, Laos (new country record), Vietnam (new country record).

Specimens examined: 1 ๙ $^{\star}$, Sa Pa (LT: 1,500 m) Lao Cai Prov. [N-VIETNAM] 15.v.2003, S. Nomura leg. (NSMT); $12 o^{\star} o^{*}, 5$ q + , N-Vietnam Lao Cai Prov., Hoanglien

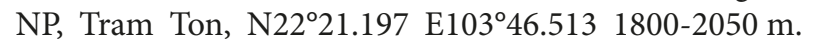
13.-16.5.2015. leg. A. Skale (ASPC); $2 \sigma^{\star} o^{\star}, 1$ ๆ , N. VIETNAM Lao Cai prov. Mt. Fan Si Pan N22 $20^{\prime} \mathrm{E} 103^{\circ} 50^{\prime}$ 22 V 2012, Binh legt. (ARPC); $10^{\star}, 3$ 우, N. VIETNAM - Lao Cai prov. Hoang Lien NP, surr. Sa Pa pass, at light $(\sim 1900 \mathrm{~m})$ 27.V.-2.VI.2011, L. Bartolozzi, S. Bambi, F. Fabiano, E. Orbach leg. (MZUF); $30^{\star} 0^{\star}$, 3 ㅇ ㅇ, NE-LAOS Hua Phan prov.: Ban Saleui, Phou Pan (Mt.) $\sim 20^{\circ} 12^{\prime} \mathrm{N} 104^{\circ} 01^{\prime} \mathrm{E}$; $1300-1900 \mathrm{~m}$ 01.-31.V.2011; leg. C. Holzschuh Ankauf ZFMK Bonn 2011 (CZPC, ZFMK); $10^{\star}, 1$ 우, LAOS-NE; HUA PHAN prov. BAN SALUEI; Phu Phan Mt.; $20^{\circ} 15^{\prime} \mathrm{N} 104^{\circ} 02^{\prime} \mathrm{E} ; 1500-2000 \mathrm{~m}$;

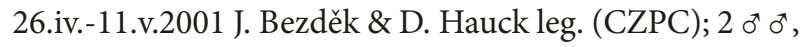
CHINA-YUNNAN 28.5.-9.6.1994 DALI lgt. Kučera (CZPC).

Remarks: Anomala yunnana was known previously from Yunnan and Guangxi provinces, China (LIN 1992, ZorN \& BEZDĚK 2016). It is here reported from northwestern Vietnam and northern Laos for the first time.

\section{Anomala zornella Prokofiev, 2015}

Distribution: Laos, Vietnam.

Specimens examined: 1 , VIETNAM, Bac Kan Prov., $\mathrm{Ba}$ Be NP, Nam Man, at light, $187 \mathrm{~m}, 22.411612^{\circ} \mathrm{N}$, 105.626792 ${ }^{\circ}$ E | IV.17-18.2010 leg. L. Papp, L. Peregovits, Z. Soltész \& G. Lengyel VN2010PL_16 (HNHM); 1 우, N-VIETNAM, Lao Cai Prov. Hoang Lien NP, Tram Ton, $22^{\circ} 21.197^{\prime} \mathrm{E} \quad 103^{\circ} 46.513^{\prime}, \quad 1800-2050 \mathrm{~m}$ 13.-16.5.2015. leg. A. Skale (ASPC); $20^{\star} o^{\star}$, Vietnam, Tam Dao 27.5.2.6.1986 Vinh Phu prov. Jan Horak lgt. (VMPC); $10^{\star}$, N-Vietnam Vinh Phuc Prov. Mt. Mo Qua. 03.V.2013 $22^{\circ} 34^{\prime} 41^{\prime \prime N} \quad 105^{\circ} 52^{\prime} 48^{\prime \prime E} \quad 700-1000 \mathrm{~m}$, leg. A. Skale (ASPC); $50^{\star} \sigma^{\star}, 2$ ㅇ ㅇ, N.-Vietnam Vinh Phu Prov., Tam Dao, 930 01.-07.V.2000 Y. Arita leg. (CZPC).

Remarks: The legs of this species are metallic red in specimens from northern Laos but metallic green in specimens from Tam Đảo and Ba Bể in northern Vietnam (Prokofiev 1915). The recently examined specimen from Trạm Tôn in northwestern Vietnam has greenish legs with red reflections and is therefore intermediate in this character.

\section{Acknowledgements}

The authors wish to express their sincere gratitude to Masayuki Fujioka (Tokyo), Yoshihisa Kusui (Okinawa), Paul K. Lago (Oxford, Mississippi), Chun Lin Li (Taipeh), Vladislav Malý (Prague), Alexander Napolov (Riga, material collected during a joint venture between the Society for Environmental Exploration (London) and the Institute for Ecology and Biological Resources (Hanoi) through the SEE-Vietnam Forest research Project in 1996-1997), Yôichi Okushima (Okayama), Petr Pacholátko (Brno), Andreas Reichenbach (Leipzig), Shûsei Saito (Chiba), Andre Skale (Hof/Saale), and Jan Strnad (Prague) for providing material from their collections for this study. Lu Yuanyuan (Beijing) kindly provided detailed photographs of specimens from the GEI collection. Moreover, we are very grateful to the collection managers and curators Luca Bartolozzi (MZUF), Pol Limbourg (RBINS), Ottó Merkl (HNHM), Johannes Frisch, Bernd Jäger and Joachim Willers (ZMB), Olivier Montreuil and Thierry Deuve (MNHN), Malcolm Kerley and Max Barclay (NHML), Eva Sprecher-Uebersax (NMBS), Dirk Ahrens (ZMFK), Matthias Hartmann (NME), Martin Fikáček, Jiří Hájek and Matthias Seidel (NMPC), Olaf Jäger and Matthias Nuss (SNSD) for preparing loans of type material and unidentified ruteline material for examination.

Paul Lago (Oxford, Mississippi, USA) corrected the English and made a number of valuable suggestions.

\section{Literature}

Arrow, G. J. 1899: On Sexual Dimorphism in Beetles of the family Rutelidae. - Transactions of the Entomological Society _of _ London. 1899-1900 (Part II): 255-269 - http://www.biodiversitylibrary.1 org/item $/ 51000 \#$ page/ $/ 9 /$ mode/ $/ 1$ up $2 \overline{0} \overline{1} \overline{7} / 0 \overline{6} / \overline{2} \overline{6}]$.

Benderitter, E. 1929: Contribution a l'étude des Rutelides du Tonkin. - Annales de la Société Entomologique de France 98: 101-109.

Burmeister, H. 1855: Handbuch der Entomologie. Vierter Band. Besondere Entomologie. Coleoptera Lamellicornia Phyllophaga chaenochela. - Enslin, Berlin: x + 569 pp. - http://www.biodiversitylibrary. org/item/34016\#page/9/mode/lup [accessed 2017/06/26].

Chandra, K. \& Gupta, D. 2012: Pleurostict scarabs (Coleoptera: Scarabaeidae): New distributional records in Arunachal Pradesh, north-east India. Check List 8: 889-893.

Fairmaire, L. 1886: Descriptions de Coléoptères de l'intérieur de la China. - Annales de la Société Entomologique de France, 6. Ser. 6: 303-356. 
Fairmaire, L. 1888: Coléoptères de l'intérieur de la Chine. - Annales de la Société Entomologique de Belgique 32: 7-46 - http://www.biodiversitylibrary. org/item/45827\#page/19/mode/1up [accessed 2017/06/26].

Fairmaire, L. 1893: Coléoptères du Haut Tokin. Annales de la Société Entomologique de Belgique 37: 303-325 - http://www.biodiversitylibrary. org/item/49378\#page/331/mode/1up [accessed 2017/06/26].

Frey, G. 1965: Neue Sericinen aus dem nordöstlichen Himalaya (Col. Melolonthidae): 88-93. - In: Hellmich, W. (ed): Khumbu Himal. Ergebnisse des Forschungsunternehmens Nepal Himalaya. Band $\mathbf{1}$ Lieferung 2 - Springer-Verlag, Berlin: 448 pp + i pl. +10 diagr. +3 maps.

FreY, G. 1970: Neue Ruteliden aus Indochina (Col. Scarab.). - Entomologische Arbeiten aus dem Museum G. Frey 21: 170-183.

Frey, G. 1971: Neue Ruteliden und Melolonthiden aus Indien und Indochina (Col.). - Entomologische Arbeiten aus dem Museum G. Frey 22: 109-133.

Frey, G. 1972: Neue Ruteliden (Col., Scarab.) aus China, Indochina und Westafrika. - Entomologische Arbeiten aus dem Museum G. Frey 23: 247-254.

Frey, G. 1975: Ergebnisse der Bhutan-Expedition 1972 des Naturhistorischen Museums in Basel. Coleoptera: Fam. Scarabaeidae Subf. Rutelinae. - Entomologica Basiliensia 1: 243-247.

Kobayashi, H. 1987: Some new rutelid beetles from Taiwan (Coleoptera, Scarabaeidae). - Elytra 15: 21-32.

Kollar, V. \& Redtenbacher, L. 1848: Aufzählung und Beschreibung der von Freiherrn Carl von Hügel auf seiner Reise durch Kaschmir und das Himaleyagebirge gesammelten Insecten: 393-564, 582-585 + xxviii pl. - In: HüGEL C. von (ed.): Kaschmir und das Reich der Siek. 4(2). Hallberger, Stuttgart: 250-865; xxxi pl., 1 map. - Thttps://archive.org/details/, "kaschmirunddasre02hg' [accessed 2017/06/26].

Lin, P. 1992: - Coleoptera: Rutelidae: 503-524. - In: Chen, S. (ed.): Insects of the Hengduan Mountains region. Volume 1., Beijing: Science Press, i-xii, 865 pp. (in Chinese and English).

Lin, P. 1996a: New species of Anomala hirsutula species group from China and discussion on their taxonomic problems (Coleoptera: Rutelidae). Entomotaxonomia 18: 157-169.

Lin, P. 1996b: Anomala cupripes species group of China and a discussion on its taxonomy. - Entomologia Sinica 3: 300-313.

Lin, P. 1999: New Species of the Genus Anomala SAmouelle (Coleoptera: Rutelidae) Collected in Yunnan, China. - Entomotaxonomia 21: 157-176.

LIN, P. 2002a: Coleoptera Rutelidae: 345-355. - In: HuAng, F. (ed.): Forest insects of Hainan. Beijing: National Natural Science Foundation of China, XV, 1-1064 pp + 31 pls (in Chinese and English).
LiN P. 2002b: Rutelidae: 387-427. - In: HuAnG, B. (ed.): Fauna of insects of Fujian Province of China. Volume 6. Fujian Science \& Technology Press, Fuzhou: 1-894 pp. (in Chinese and English).

Miyake, Y. 1994: New or little known Scarabaeid Beetles from Southeast-Asia II. - Special Bulletin Essa entomological Society 2: 139-156.

MiYAKe, Y. 1996: New or little known Scarabaeid Beetles from Southeast-Asia III. - Lamellicornia 11: 33-54.

Miyake, Y. 2000: New or little known scarabaeid beetles from Southeast Asia IV. - Science Report of the Research Institute of Evolutionary Biology 9: 105-120.

Murányi, D. \& Li, W. H. 2015: Klapálek’s Kamimuria (Plecoptera: Perlidae) types in the National Museum Prague. - Opuscula Zoologica Budapest 46(2): 159-175.

Nguyen, T. T. H. \& WadA, K. 2006: A new species of the genus Mimela (Coleoptera, Scarabaeidae, Rutelinae) from Vietnam. - Kogane 7: 61-64.

Nonfried, A. F. 1892: Verzeichnis der um Nienghali in Südchina gesammelten Lucanoiden, Scarabaeiden, Buprestiden und Cerambyciden, nebst Beschreibung neuer Arten. - Entomologische Nachrichten (Berlin) 18: 81-95.

OHaus, F. 1905: Beiträge zur Kenntnis der Ruteliden. Deutsche Entomologische Zeitschrift 1905: 81-99.

Ohaus, F. 1914: XV. Beitrag zur Kenntnis der Ruteliden. - Entomologische Zeitung 75: 193-217 - https://www. biodiversitylibrary.org/page/8825521\#page/205/ mode/1up [accessed 2017/10/12].

OHAus, F. 1915: Beitrag zur Kenntnis der palaearktischen Anomala-Arten. - Stettiner entomologische Zeitung 76: 302-331 - https://www.biodiversitylibrary. org/page/8826074\#page/314/mode/1up [accessed 2017/10/13].

PAulian, R. 1959: Coléoptères Scarabéides de l'Indochine (Rutélines et Cétonines) (suite). - Annales de la Société Entomologique de France 128: 35-136 http://gallica.bnf.fr/ark:/12148/bpt6k6142156w/f14 [accessed 2017/06/26].

Prokofiev, A. M. 2012a: Two new species of the genus Anomala SAM. from Central Vietnam (Coleoptera: Scarabaeidae). - Russian Entomological Journal 21(4): 385-393 _ - Thttp://kmkjournals.com/journals/REJ//

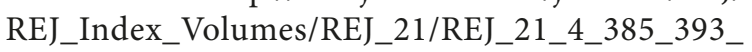
Prokofiev [accessed 2017/10/12].

Prokofiev, A. M. 2012b: New and noteworthy pleurostict scarab beetles_(Coleoptera: Scarabaeidae). - Calodema 220: 1-33 _https://www.zin.ru/animalia/, coleoptera/pdf/prokofiev_scarabaeidae_calodema.ı

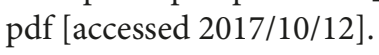

Prokofiev, A. M. 2013a: A new genus of Anomalini from Vietnam (Coleoptera: Scarabaeidae: Rutelinae). - Russian Entomological Journal 22(1): 5-7 - htttp:/// kmkjournals.com/upload/PDF/REJ/22/ent 22 1\%20 $1005007 \% 20$ Prokofiev\%20 for $\% 20$ Inet.p $2 \overline{0} \overline{\overline{1}} \overline{\overline{7}} / \overline{0} \overline{\mathrm{\sigma}} / \overline{2} \overline{\mathrm{C}}]$. 
Prokofiev, A. M. 2013b: New Anomala species from Vietnam. - Russian Entomological Journal 22(2): 97-109 _ _ _tttp://kmkjournals.com/upload/PDF/, $R E J / 22 /$ ent $22-2 \% 20097-109 \% 20$ (Prokofiev) $\% 20$

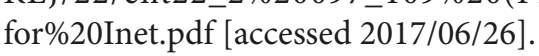

Prokofiev, A. M. 2013c: Two new species of the Anomala aulax-group from Central Vietnam (Coleoptera, Scarabaeidae, Rutelinae). - Euroasian Entomological Journal 12(6): 553-558 [in Russian] _ . http://kmkjournals.com/upload/PDF/EEJ/12/, EEJ12_6_553_558_Prokofiev.pdff $20 \overline{1} \overline{7} / \overline{1} \overline{0} / \overline{1} \overline{2}]$.

Prokofiev, A. M. 2014a: New and little-known species of Anomala SAM. of the fauna of Vietnam (Coleoptera, Scarabaeidae, Rutelinae). - Euroasian Entomological Journal 13: 15-25 [in Russian].

Prokofiev, A. M. 2014b: New and noteworthy scarab beetles from Asia and America (Coleoptera Lamelli-, cornia) - Calodema 330: 1-25 - https://www.zin.' ru/Animalia/Coleoptera/pdf/prokofiev_2014

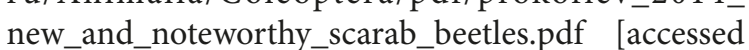

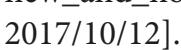

Prokofiev, A. M. 2015a: New Anomala SAmouelle, 1819 from South-East Asia (Coleoptera: Scarabaeidae: Rutelinae). - Russian Entomological Journal 24: 37-59 - _ _ n http://kmkjournals.com/upload/PDF/REJ/24/i

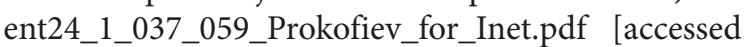
$2 \overline{0} \overline{1} \overline{7} / \overline{0} \overline{6} / \overline{2} \overline{6}]$.

Prokofiev, A. M. 2015b: An unusual new species of the genus Anomala Samouelle, 1819 from Vietnam (Coleoptera: Scarabaeidae: Rutelinae). - Caucasian Entomological Bulletin 11: 25-27.

Prokofiev, A. M. \& Zorn, C. 2016: Review of the Mimela species of the Dalat Plateau in southern Vietnam (Coleoptera, Scarabaeidae, Rutelinae). Contributions to Entomology 66(2): 329-346 - DOI: $10.21248 /$ contrib.entomol.66.2.329-346.
Wiedemann, C. R. W. 1823: Zweihundert neue Käfer von Java, Bengalen und dem Vorgebirge der guten Hoffnung. - Zoologisches Magazin 2(1): 3-133.

Zhang, B. \& Lin, P. 2008: The Anomala sinica species group from China (Coleoptera: Rutelidae):-_ Oriental Insects 42: 125-141 - DOI:110.1080/00305316.2008.10417539',

ZorN, C. 2005: Taxonomical acts in the Analini initiated during the preparation of the "Catalogue of Palaearctic Coleoptera". - Acta Societatis Zoologicae Bohemicae 68: 310-328.

Zorn, C. 2006: Scarabaeidae: Rutelinae: Anomalini. - In: Löbl, I. \& Smetana, A. (eds): Catalogue of Palaearctic Coleoptera. Vol.3. - Apollo Books, Stenstrup, pp. 251-276.

Zorn, C. 2007: Taxonomic revision of the Anomala cuprascens - species group of Sulawesi and the Papuan region: The species with unidentate protibiae (A. chlorotica-subgroup) (Coleoptera: Scarabaeidae: Rutelinae). - _ Arthropod Systematics_\&_Phylogeny 65: 25-71 - http://www.senckenberg.de/files/content// iforschung/publikationen/arthropodsystematics, asp_65_1/asp_65_1_zorn_25-71.pdf $\overline{2} \overline{0} \overline{1} \overline{7} / \overline{0} \overline{6} / \overline{2} \overline{6}]$.

Zorn, C. 2011: New species of the genus Anomala SAmouelle from mainland South East Asia and South China. - Stuttgarter Beiträge _zur Naturkunde A, Neue Serie 4: 297-312 _ _http:/// www.naturkundemuseum-bw.de/sites/default/files/, publikationen/serie-a/ns04-15zorn.pdf $\overline{2} \overline{0} \overline{1} \overline{7} / \overline{0} \overline{6} / \overline{2} \overline{6}]$.

Zorn, C. \& BEZDĚK, A. 2016: Rutelinae.: 317-358. - In: LöBL, I. \& LöBL, D. (eds): Catalogue of Palaearctic Coleoptera. Volume 3. Scarabaeoidea - Scirtoidea Dascilloidea - Buprestoidea - Byrrhoidea. - Revised and updated edition - Brill, Leiden, Boston: 317-358 - ISBN 9789004309135 - http://Www.brill.com/1 scarabaeooidea-scirtoidea-dascilloidea-buprestoidea-1 and-byrrhoidea [accessed 2017/06/26]. 